$$
0,56=203
$$

\title{
Ground-Temperature Measurements
}

\author{
Part I, Pallmann Technique
}

By Daniel R. Norton and IRVING Friedman

Part II, Evaluation of the Pallmann Technique in Two Geothermal Areas of West-Central Nevada

By F. H. Olmsted, IRving Friedman, and Daniel R. NORTON

Part III, Ground Temperatures in and near Yellowstone National Park

By IRVING Friedman and Daniel R. Norton

G E O L O G I C A L S U R V E Y P R O F E S S I O N A L P A P E R 12203

\section{NOTICE}

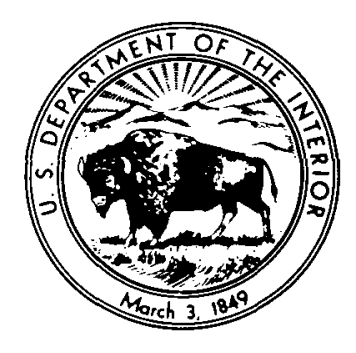

PORTIONS OF THIS REPORT ARE ILLEGIBLE It

has been reproduced from the best anilable

copy to permit the broadest possiblo araik

abilita

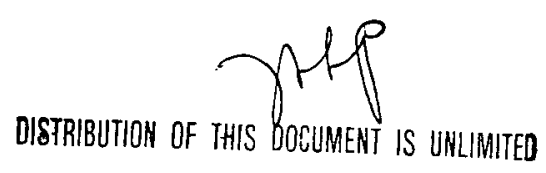

UNITED STATES GOVERNMENT PRINTING OFFICE, WASHINGTON : 1981 


\section{DISCLAIMER}

This report was prepared as an account of work sponsored by an agency of the United States Government. Neither the United States Government nor any agency Thereof, nor any of their employees, makes any warranty, express or implied, or assumes any legal liability or responsibility for the accuracy, completeness, or usefulness of any information, apparatus, product, or process disclosed, or represents that its use would not infringe privately owned rights. Reference herein to any specific commercial product, process, or service by trade name, trademark, manufacturer, or otherwise does not necessarily constitute or imply its endorsement, recommendation, or favoring by the United States Government or any agency thereof. The views and opinions of authors expressed herein do not necessarily state or reflect those of the United States Government or any agency thereof. 


\section{DISCLAIMER}

Portions of this document may be illegible in electronic image products. Images are produced from the best available original document. 


\section{UNITED STATES DEPARTMENT OF THE INTERIOR}

\section{JAMES G. WATT, Secretary}

\section{GEOLOGICAL SURVEY}

Doyle G. Frederick, Acting Director

Catalog No. 81-607982

\footnotetext{
T For sale by the Superintendent of Documents, U.S. Government Printing Office
} Washington, D.C. 20402 


\section{CONTENTS}

Part I, Pallmann technique, by Daniel R Norton and Irving Friedman

Part II, Evaluation of the Pallmann technique in two geothermal areas of west-central

Nevada, by F. H. Olmsted, Irving Friedman, and Daniel R. Norton ................ 13

Part III, Ground Temperatures in and near Yellowstone National Park,

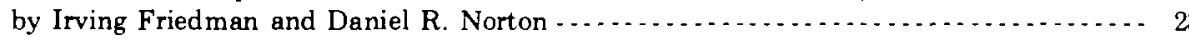


GROUND TEMPERATURE MEASUREMENTS

\title{
PART I, PALLMANN TECHNIQUE
}

\author{
By Daniel R. NORTON and IRVING FRIEDMAN
}

\section{CONTENTS}

\begin{tabular}{|c|c|c|c|}
\hline & Page & & Page \\
\hline Preparation of Pallmann solutions $\ldots \ldots \ldots \ldots$ & 2 & Precision of the method & 4 \\
\hline Temperature probe $(\ldots, \ldots \ldots \ldots \ldots$ & 2 & 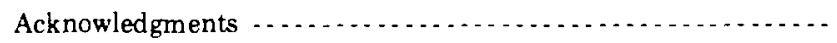 & 5 \\
\hline
\end{tabular}

FiguRE 1. Sixteen graphs showing plots of temperature range of a sample for 1 year versus effective temperature calculated for

\section{ILLUSTRATION}

\section{TABLES}

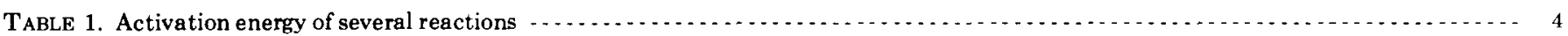

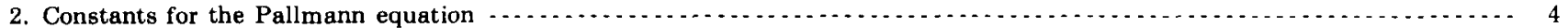

3. Pallmann temperatures during 1977 at Bunsen Peak site as measured using two solutions of different pH $\ldots \ldots \ldots \ldots$

4. Pallmann temperatures during 1978 at two sites as measured using solution of $\mathrm{pH} 1.93 \ldots \ldots \ldots$

\section{ABSTRACT}

The measurement of integrated ground temperatures by the use of the Pallmann method was investigated in the laboratory and in the field. The method makes use of the fact that the rate of inversion of a solution of sucrose to invert sugar is temperature-dependent and can be easily monitored. The rate, which is also a function of the $\mathrm{pH}$ of the solution, can be adjusted so that the reaction is only partially completed during the time that the temperature is to be monitored. Laboratory calibration of the solution is necessary if accuracies of $0.25^{\circ}$ Celsius (C) are to be achieved.

Probes containing Pallmann solution at 1-meter (m) and 2-m depths were designed for insertion into the ground. A method for making 2-mdeep holes in the ground was developed that combines pounding a small steel rod into the ground and then enlarging this small hole by blasting with Primacord.
Field tests using these techniques show that the effective temperature, integrated over the annual temperature cycle at soil depths of 1 and $2 \mathrm{~m}$ can be measured with an accuracy of about $0.25^{\circ} \mathrm{C}$. Differences in temperature between 1 and $2 \mathrm{~m}$, and between adjacent probes can be measured to about $0.05^{\circ} \mathrm{C}$.

Figures are given which allow Pallmann-effective temperatures to be converted to arithmetic-mean temperatures, obsidian-hydration effective temperatures, and Ambrose-effective temperatures. In order to use these figures, the range in temperature experienced by the sample for the time period under consideration must be known, or estimated. A novel method of determining the temperature range utilizes two cells containing materials whose activation energy differs. These cells are buried side by side.

PARTS II and III of the present paper describe field use of the Pallmann method. 


\section{INTRODUCTION}

Ground-temperature data are needed to date rhyolite flows and glacial moraines that contain rhyolite glass by the obsidian-hydration method and to date organic materials by the amino-acid-racemization dating technique. Shallow ground temperatures may also be useful in detecting and delineating thermal anomalies in potential geothermal-resource areas.

For a number of years, the authors measured ground temperatures by burying temperature sensors in the soil and connecting them to various types of recorders. At many places this method was not feasible because electric power was not available, and access for servicing in the winter was difficult. In addition, malfunctions of the recorders and the necessity of changing recorder charts required frequent visits. In addition, thousands of points had to be read from the charts and then transferred to a computer to calculate average or integrated annual temperatures. The total cost of this method of temperature measurement is high.

A method for temperature measurement more convenient and less expensive than continuous recording, and applicable to remote areas, is the Pallmann method of temperature measurement, first described by Pallmann and others (1940). This method makes use of the fact that an aqueous solution of sucrose slowly hydrolyzes to invert sugar (mixture of glucose and fructose). The rate of this reaction is temperature- and $\mathrm{pH}$-dependent. The higher the temperature the more rapidly the reaction proceeds. The reaction is easily monitored inasmuch as the sucrose has a different angle of rotation of polarized light than the invert sugar, and the rotation can be measured with a polarimeter. Pallmann and others (1940) investigated this reaction extensively and proposed its use for measuring temperatures in the soil for biological investigations. Other investigators (Schmitz, 1964; Schmitz and Volkert, 1959; Lee, 1969; O'Brien, 1971) used the Pallmann method and reported precision on the order of a few hundredths of a degree Celsius. These results, plus convenience, prompted us to investigate the technique as a replacement for the continuous-recording method.

\section{PREPARATION OF PALLMANN SOLUTIONS}

The Pallmann solution is a sucrose solution in aqueous media using a citric acid-sodium citrate buffer. Reagentgrade chemicals and distilled water were used. Formaldehyde was added to prevent deterioration of the solution by bacterial growth. Because the sucrose hydrolysis reaction is catalyzed by acid, it was necessary to adjust the $\mathrm{pH}$ of the solution to $\pm 0.02 \mathrm{pH}$ units. The Pallmann solutions were made according to the technique given by Schmitz (1964). The solutions were im- mediately bottled in ampoules or polypropylene bottles, and stored in a freezer at $-32^{\circ} \mathrm{C}$. The glass ampoules were made of 15 -mm o.d. (millimeters outside diameter) tubing with a narrow neck for sealing, and contained 4 $\mathrm{ml}$ (milliliters) of solution.

\section{TEMPERATURE PROBE}

In order to measure effective ground temperatures by the Pallmann method it is necessary to bury small amounts of sucrose solution sealed in glass ampoules and to be able to retrieve these ampoules after a suitable period of time. Our ampoules were about $15 \mathrm{~mm}$ in diameter and contained $4 \mathrm{ml}$ of solution. These ampoules were inserted into probes for insertion into the ground. Our probes were constructed of plastic water pipe $(1 / 2$-inch $(12.7-\mathrm{mm})$ diameter water pipe). One vial was placed at the bottom of the 2 - $\mathrm{m}$ long probes in a small brass container and another vial was placed at the 1-m position of the same probe enclosed in a brass sleeve to make good thermal contact with the ground. Styrofoam pellets were packed inside the pipe to prevent convection currents. The plastic probe was capped by a metal pipe cap. The probe was buried just below the surface of the ground and the earth was well tamped around it to eliminate air space between soil and probe. In order to locate the probe we mapped its location and then used a metal detector to detect the metal pipe cap at the top of the probe. This technique proved highly successful and we have had no difficulty in locating probes in remote, and in some places featureless, terrain.

When the probes were removed from the ground the Pallmann ampoules were retrieved from the probes and were immediately placed upright in a container of dry ice to freeze. Freezing in the upright position prevented stresses that might have cracked the ampoule.

\section{EMPLACEMENT OF TEMPERATURE PROBE}

Different methods of drilling holes to emplace the probes containing Pallmann solution, as well as different designs of probes, were evaluated. Hand augering of the 1 -in. $(2.5-\mathrm{cm})$ diameter holes to $2-\mathrm{m}$ depth was of marginal usefulness. It was slow and extremely difficult because the soil often contained pebbles and cobbles. However, this method of emplacing probes has been used on a few occasions. We also investigated the use of lightweight portable gasoline-driven drills. The problem with this technique was the plugging of the 2-m-long auger bit. In addition, the difficulty of handling the 2-mlong drill bits added complications. Small pebbles or cobbles also defeated this device. 
The most successful method of emplacing the probes has been to use Primacord' to enlarge a small hole. The Primacord method was to first pound into the ground a steel device consisting of an outer thin steel tube $/ /_{6}$ in. o.d. and $1 / 4$ in. i.d. (inside diameter) and an inner steel rod having a diameter slightly less than $1 / 4$ in. The inner rod was then withdrawn and Primacord (50 grains per foot) was threaded down the tube to the bottom of the hole. The outer steel tube was then withdrawn, leaving the Primacord in place in the soil.

Upon detonation, the Primacord enlarges the hole from its initial $/ 6$-in. diameter to approximately $1.5 \mathrm{in}$. in diameter. The Primacord is a relatively safe explosive because it cannot be detonated without the use of powerful detonators. The exploding bridgewire detonator that we are using is also relatively safe because it contains no sensitive explosive but is detonated by the shock wave produced by an exploding wire. This thin ( 0.001 in.) gold wire is exploded by passing a high current (approximately 1000 amperes) at high voltage (approximately 3000 volts) through the wire for a short period ( 1 microsecond). These detonators can only be activated by the use of a special detonation box. We have emplaced several hundred probes using this technique without incident. The noise made by the detonating Primacord is equivalent to that of a 12-gauge shotgun and it can be sufficiently muffled so that a person standing $50 \mathrm{~m}$ away can hardly hear the detonation.

\section{MEASUREMENT OF OPTICAL ROTATION}

Optical rotation was measured with a Rudolph Model 52A2 Polarimeter with a mercury lamp at $546.07 \mathrm{~nm}$ (nanometer). Digital readout of optical rotation was read to the nearest 0.01 degree. Water-jacketed polarimeter sample cells $200 \mathrm{~mm}$ long with a capacity of $2.5 \mathrm{ml}$ were used throughout this study. Special glass filters were used to isolate the $546.07-\mathrm{nm}$ line. The optical rotation of an NBS.(National Bureau of Standards) quartz control plate was determined with each group of measurements. Over a 2-year period we found that the standard deviation of the measurement of the quartz plate was a 0.05 degree rotation. All optical rotation measurements reported by our method are the average values for 10 readings corrected for instrument zero.

Prior to measurements, the ampoules were removed from the freezer, held in the hand to melt the solution, and constantly shaken. As soon as the crystals melted completely the ampoules were placed in a circulator-

'Primacord is a high-explosive (pentacrythrotrol trinitrate) filled cord manufactured by Ensign Bickford Co., Simsbury, Conn. 06070. The exploding bridgewire detonators and the special detonating box are made by Reynoldis Industries, Inc., P.O. Box 1176, Marina Del Ray, Calif. Any trade names and trademarks found in this publication are used for descriptive pur poses only and do not constitute endorsement by the U.S. Geological Survey water bath at $20.00^{\circ} \mathrm{C}$ and were kept there for 10 minutes with intermittent shaking. During this period the waterjacketed polarimeter tube sample cell was equilibrated to $20.00^{\circ} \mathrm{C}$. Immediately after this equilibrium period the ampoules were opened and the Pallmann solutions were transferred with a narrow glass pipette into the polarimeter cell. It is important that the Pallmann solution, which is viscous, be introduced from the bottom of the cell to avoid air entrapment. After securing the cap on the end of the cell, another 5-minute period was allowed for temperature equilibrium. Readings were then immediately taken to reduce errors due to continued hydrolysis.

\section{EFFECTIVE TEMPERATURE}

The rate of the Pallmann reaction, in common with many chemical and physical processes, responds in a nonlinear manner to temperature. A positive temperature change will speed up the cumulative reaction more than an equivalent negative temperature change will slow it down. Therefore, if the sucrose solution experiences a fluctuating temperature, the reaction will be the same as if the sucrose was exposed to a constant temperature that is higher than the arithmetic-mean temperature. This calculated constant temperature is referred to as the "effective temperature".

Because the Pallmann reaction responds nonlinearly with respect to temperature, the values calculated by this method are not arithmetic means but are logarithmic-integrated temperatures. These can be converted to arithmetic means if the range in temperature is known, as shown by Lee (1969). For many purposes, including obsidian and amino-acid dating, integrated (effective) temperatures are more actually useful than arithmetic means, because the reactions being monitored (diffusion of water into volcanic glass, racemization of amino acids) also respond to temperature changes exponentially, not linearly. The closer the activation-energy rate constant of the monitoring method is to that of the reaction being monitored, the more accurate the integrated temperature will be. This can be illustrated as follows.

Given a temperature that varies sinusoidally between $+5^{\circ}$ and $-5^{\circ} \mathrm{C}$. The arithmetic average temperature is $0^{\circ} \mathrm{C}$. The integrated or effective temperature for a reaction having an activation energy of $20 \mathrm{kcal} / \mathrm{mole}$ (kilocalories per mole) is $+0.74^{\circ} \mathrm{C}$; if the activation energy is $10 \mathrm{kcal} / \mathrm{mole}$, the integrated temperature is $+0.43^{\circ} \mathrm{C}$. If the amplitude of the temperature variation is doubled to $+10^{\circ}$, or to $-10^{\circ}$, the mean temperature will remain zero but the two integrated temperatures will now be $2.75^{\circ} \mathrm{C}$ and $1.66^{\circ} \mathrm{C}$, respectively.

In the previous example of a sinusoidally varying temperature, the integrated or effective temperature is 
seen to vary mainly as a function of the temperature range and the activation energy of the reaction. The activation energies of the reactions to be considered in this paper are shown in table 1.

TABLE 1.-Activation energy of several reactions

\begin{tabular}{cc} 
Reaction & $\begin{array}{l}\text { Activation } \\
\text { energy, in } \\
\mathbf{k c a l} / \mathrm{mole}\end{array}$ \\
\hline
\end{tabular}

Water diffusion through plastic (Ambrose cell) ............'11.7 Water diffusion into obsidian-hydration dating) ........... Inversion of sucrose (Pallmann solution) - . . . . . . . . . . - . 27.0 Isoleucine amino-acid racemization (amino-acid dating) - . - - 27.5

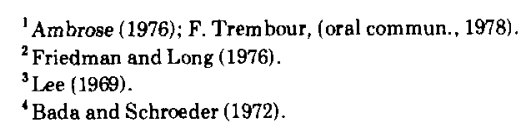

The rate at which the sucrose inverts to invert sugar is dependent upon the $\mathrm{pH}$ of the solution as well as upon temperature. By adjusting the initial $\mathrm{pH}$, we prepared solutions that were useful for different effectivetemperature ranges. The basic equation, as originally proposed by Pallmann and others (1940) is:

$$
T\left({ }^{\circ} K\right)=\frac{-a}{\mathrm{pH}-b-\log t+\log \left[\log \left(R_{\mathrm{o}}-R_{\alpha}\right)-\log \left(R_{\mathrm{t}}-R_{\omega}\right)\right]} \text {, }
$$

$$
\text { where } \begin{aligned}
T & =\text { integrated temperature in degrees Kelvin }(K) \\
a & =\text { constant } \\
b & =\text { constant } \\
t & =\text { time, in days } \\
R_{0} & =\text { rotation angle of sucrose solution at time } t=0 \\
R_{t} & =\text { rotation angle of sucrose solution at time }=t \\
R_{\infty} & =\text { rotation angle of sucrose solution at time }=\infty \text { (infinity). } \\
& \text { This is the rotation angle when all of the sucrose } \\
K & =\text { has inverted to invert sugar. }
\end{aligned}
$$

\section{ACCURACY OF THE PALLMANN METHOD}

In the $\mathrm{pH}$ range used in our investigation ( $\mathrm{pH} 1.5-3.0)$, a difference of $0.01 \mathrm{pH}$ unit corresponds to an annual temperature increment of $0.13^{\circ} \mathrm{C}$. It is difficult to measure $\mathrm{pH}$ with an accuracy of \pm 0.01 units. The $\mathrm{pH}$ changes slightly with temperature and also changes as the reaction proceeds (Lee, 1969). Therefore, we calibrated our Pallmann solutions by measuring the change in rotation when aliquots of the solutions were kept in constant temperature baths for known time periods. The baths used were constant to $\pm 0.01^{\circ} \mathrm{C}$, and the temperatures were read to $\pm 0.05^{\circ} \mathrm{C}$ using thermometers calibrated against NBS standards. The sealed vials containing the solutions were kept in the water baths for periods of time from 1 day to 3 months at temperatures from $20^{\circ}$ to $45^{\circ} \mathrm{C}$. The rotation angles were measured and corrected according to figure $2 d$ of Schmidt and Volkert (1959), recalculated for mercury light. At the conclusion of the experiment, reaction-rate constants were calculated using the corrected rotations, the known time, and the measured $\mathrm{pH}$. The constants proposed by Pallmann and others (1940) and those calculated by us are given in table 2 .

Temperatures calculated for the $\mathrm{pH} 1.93$ solution using our constants are about $1^{\circ} \mathrm{C}$ lower than those using the original Pallmann constants. On the other hand, the temperatures calculated for the $\mathrm{pH} 2.51$ solution with our constants are within $0.2^{\circ} \mathrm{C}$ of those calculated using the Pallmann constants. This discrepancy may be due to errors in our $\mathrm{pH}$ measurements. The $\mathrm{pH}$ meter had to be calibrated using $\mathrm{pH} 7$ and 4 buffers. The buffer values were known to \pm 0.01 . The farther the $\mathrm{pH}$ to be measured is from this $\mathrm{pH}$ range, the greater the error in the $\mathrm{pH}$ measurement. If the actual $\mathrm{pH}$ of the low $\mathrm{pH}$ Pallmann solution was 1.87 rather than the measured value of 1.93 , the Pallmann constants would yield exact temperature values.

A check on the accuracy to be expected using the Pallmann method was carried out in the field using probes. buried in the ground and placed $1 \mathrm{~m}$ apart. These probes contained vials of Pallmann solution at 1 - and $2-\mathrm{m}$ depths.

Four probes were spaced in an array where two of the probes contained solutions of $\mathrm{pH} 1.93$ and the other two contained solutions of $\mathrm{pH} 2.51$. All the probes were buried at one time, and all were removed 1 year later. The results are shown in table 3 . The $\mathrm{pH} 1.93$ solutions yielded temperatures that are about $0.25^{\circ} \mathrm{C}$ higher than those of the $\mathrm{pH} 2.51$ solutions. The accuracy of the Pallmann method is about $0.25^{\circ} \mathrm{C}$, and is limited primarily by the difficulty in determining the $\mathrm{pH}$ to closer than 0.02 unit.

T ABLE 2.-Constants for the Pallmann equation

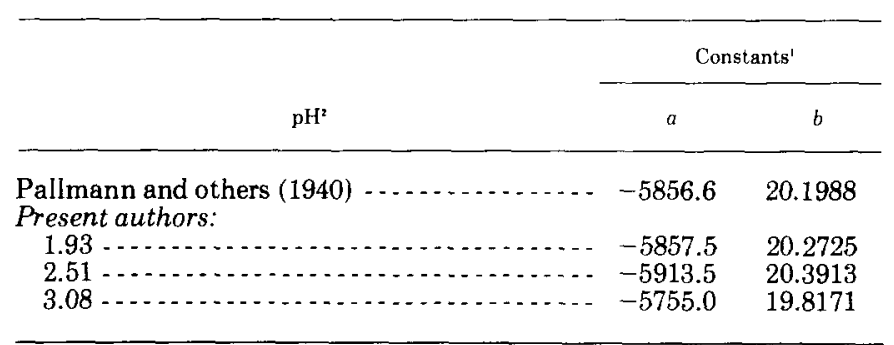

' $a$ and $b$ are constants given in equation 1.

${ }^{2}$ Constants derived by Pallmann and others (1940) are independent of $\mathrm{pH}$

\section{PRECISION OF THE METHOD}

The precision of the method-that is how precisely can small temperature differences be measured-is far 
better than $0.25^{\circ} \mathrm{C}$. Under laboratory conditions, using a constant temperature bath, temperature differences as small as $0.05^{\circ} \mathrm{C}$ can be resolved. Under natural conditions, the limiting factor is the inherent "noise" because there are ground-temperature differences between sites as closely spaced as $1 \mathrm{~m}$ due to inhomogenieties in soil diffusivity, surface albedo, thermal inertia, and other variables.

In addition to the array given in table 3 , two other arrays with multiple probes containing the $\mathrm{pH} 1.93$ solution were emplaced $1 \mathrm{~m}$ apart and were measured after being buried for 1 year. The results are given in table 4 . The $0.12^{\circ} \mathrm{C}$ difference at the Bunsen Peak site $1-\mathrm{m}$ depth may be real, inasmuch as a difference of $0.16^{\circ} \mathrm{C}$ was found the previous year at the same site (see table 3 ). The temperatures at $2-\mathrm{m}$ depth were the same for both years at this site. From the above data it can be seen that a precision of $\pm 0.02^{\circ} \mathrm{C}$ can be realized by the Pallmann method.

The many curves shown in figure 1 (at end of PART I) define the relationships among the three parameters: (1) arithmetic-mean temperature, (2) effective temperature, and (3) temperature range for the different processes of sucrose inversion, obsidian hydration, and diffusion of water through methyl methacrylate plastic. The data for this figure were calculated assuming that the temperature varied sinusoidally (harmonically) through the temperature range plotted on the abscisa. From this figure, if the temperature range is approximately known, then Pallmann or Ambrose-effective temperature can be converted to obsidian-hydration or amino-acid effective temperatures, or to arithmeticmean temperatures. Plots are given for $2^{\circ} \mathrm{C}$-increments in arithmetic mean temperature from $0^{\circ}$ to $30^{\circ} \mathrm{C}$.

The Ambrose technique is another method for temperature integration (Ambrose, 1976). It is based upon the temperature dependence of the rate of diffusion of water into a plastic cell.

Figure 1 shows that the Pallmann effective temperatures are somewhat higher than the obsidian-hydration effective temperatures.

Because the activation energy of the isoleucine aminoacid racemization is close to that of the Pallmann reaction $(27.5 \mathrm{kcal}$ versus $27.0 \mathrm{kcal})$, the effective temperatures measured by the Pallmann method will be close approximations to the amino-acid effective temperatures. The Ambrose method yields effective temperatures that are lower than both the Pallmann and obsidian temperatures.

If the temperature range can be determined, the Ambrose and Pallmann effective temperatures can be converted to amino-acid or obsidian-hydration effective temperatures, or to arithmetic-mean temperatures.
By burying a Pallmann vial next to an Ambrose cell, the effective temperature for each can be measured, and then the temperature range can be calculated from the difference in effective temperatures. For example, if the Pallmann vial yields an effective temperature of $15.1^{\circ} \mathrm{C}$, and the Ambrose cell gives an effective temperature of $12.5^{\circ} \mathrm{C}$, the range in temperature is $26.0^{\circ} \mathrm{C}$, and the mean temperature is $10.0^{\circ} \mathrm{C}$ (see fig. 1). PARTS II and III of the present paper give applications of the Pallmann technique.

TABLE 3.-Pallman temperatures during 1977 at Bunsen Peak site' as measured using two solutions of different $p H$

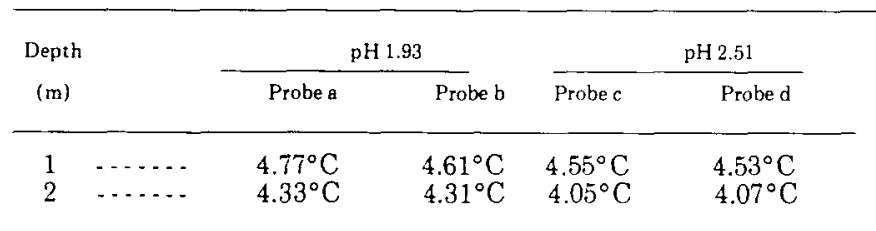

'See PART III for description of this site.

TABLE 4.-Pallmann temperatures during 1978 at two sites as measured using solutions of $\mathrm{pH} 1.93$

\begin{tabular}{|c|c|c|c|c|c|}
\hline \multirow{2}{*}{$\begin{array}{c}\text { Depth } \\
(\mathrm{m})\end{array}$} & & \multicolumn{2}{|c|}{ Bunsen Peak site' } & \multicolumn{2}{|c|}{ Turbid Lake site' } \\
\hline & & Probe a & Probe b & Probe a & Probe b \\
\hline $\begin{array}{l}1 \\
2\end{array}$ & $\ldots \ldots$ & $\begin{array}{l}4.54^{\circ} \mathrm{C} \\
4.35^{\circ} \mathrm{C}\end{array}$ & $\begin{array}{l}4.42^{\circ} \mathrm{C} \\
4.31^{\circ} \mathrm{C}\end{array}$ & $\begin{array}{l}5.34^{\circ} \mathrm{C} \\
5.44^{\circ} \mathrm{C}\end{array}$ & $\begin{array}{l}5.36^{\circ} \mathrm{C} \\
5.46^{\circ} \mathrm{C}\end{array}$ \\
\hline
\end{tabular}

'See PART III for description of this site.

\section{ACKNOWLEDGMENTS}

We owe a great debt of thanks to William Long who designed and constructed the steel device used to emplace the Primacord. He also designed the plastic probe and was most helpful at all stages of the research. Gary Giarratano and Mary Robison assisted in the laboratory phase of the research.

\section{REFERENCES CITED}

Ambrose, W., 1976, Intrinsic hydration rate dating of obsidian, Chapter 5 in R. E. Taylor, ed., Advances in obsidian glass studies: Park Ridge, N. J. Nayes Press, p. 81-106.

Bada, J. L., and Schroeder, R. A., 1972, Racemization of isoleucine in calcareous marine sediments; kinetics and mechanism: Earth and Planetary Science Letters, v. 15, no. 1, p. 1-11.

Friedman, I., and Long, W., 1976, Hydration rate of obsidian: Science, v. 191 , no. 4225 , p. $347-352$.

Lee, R., 1969, Chemical temperature integration: Joumal of Applied Meteorology, v. 8, p. 423-430.

O'Brien. P. J., 1971, Pallmann method for mass sampling of soil, water, or air temperatures: Geological Society of America Bulletin, v. 82 , no. 10 , p. $2927-2932$. 
Pallmann, H., Eichenberger, E., and Hasler, A., 1940, Eine neue Methode der Temperaturmessung bei okologischen oder bodenkundlichen Untersuchungen: Berichte der Schweizerishen Botan. ischen Gesellschaft, v. 50, p. 337-362.

Schmitz, W., 1964, Messprobleme bei reaktionskinetischen Untersuchungen mit dem Kreispolarimeter dargestellt am Beispiel der reaktionskinetischen Temperaturmessung: Zeiss Mitteilungen, v. 3 , p. 227-249. U.S. Department of Commerce Technical Transla- tion TT67-61038, Washington, D.C., 1966 [English translation]. Schmitz, W., and Volkert, E., 1959, Die Messung von Mitteltemperaturen auf reaktionskinetischer Grundlage mit dem Kreispolarimeter und ihre Anwendung in Klimatologie und Biookologie, speziell in Forst- und Gewasserkunde: Zeiss Mitteilungen, v. 1, p. 300-337. U.S. Department of Commerce Technical Translation TT67-62408, Washington, D. C., 1966 [English translation]. 


\section{FIGURE 1}

Plots of the temperature range experienced by a sample versus the effective temperatures calculated for the Pallmann reaction, the obsidian-hydration reaction, and the Ambrose method. In making the calculations we used equation 2 and assumed a harmonic or sinusoidal temperature variation with an amplitude given by the "temperature range", and an activation energy for each reaction as follows: Pallmann (27 kcal/mole), obsidian-hydration (19.7 kcal $/ \mathrm{mole})$, Ambrose $(11.7 \mathrm{kcal} / \mathrm{mole}$ ). Sets of curves are given for different arithmetic means from $0^{\circ}$ to $30^{\circ}$ Celsius in $2^{\circ}$-intervals. The effective temperature equals the arithmetic mean temperature when the temperature range equals zero.

$$
t=e^{\frac{-E}{R T}}+273.2
$$

where $t=$ effective temperature in degrees Celsius

$e=$ base of natural logarithms

$E=$ activation energy

$R=$ gas constant, $1.98 \mathrm{cal} / \mathrm{mole}$

$T=$ temperature in degrees Kelvin. This temperature varies sinusoidally with an amplitude given by "temperature range". 

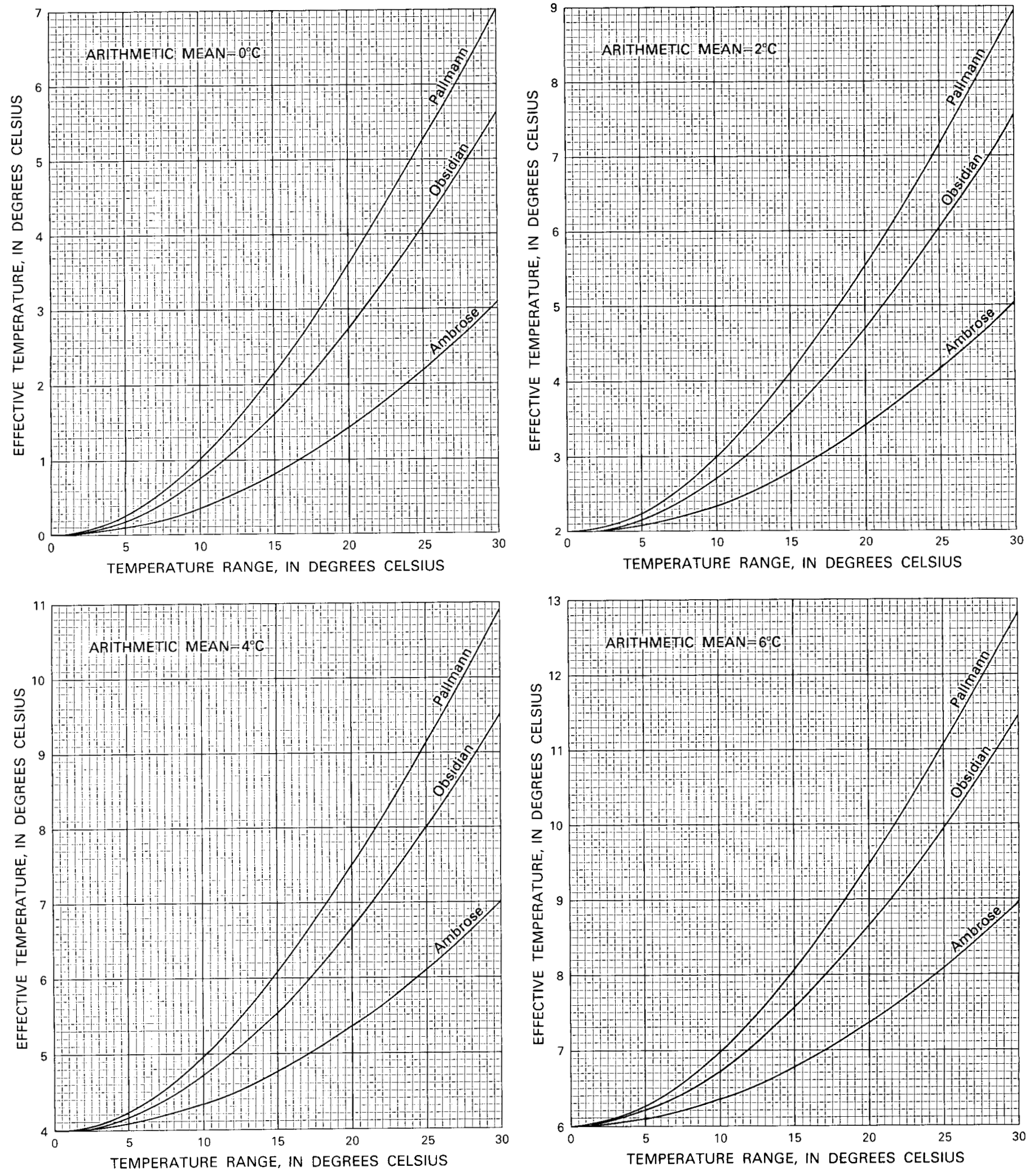
FIGURE 1
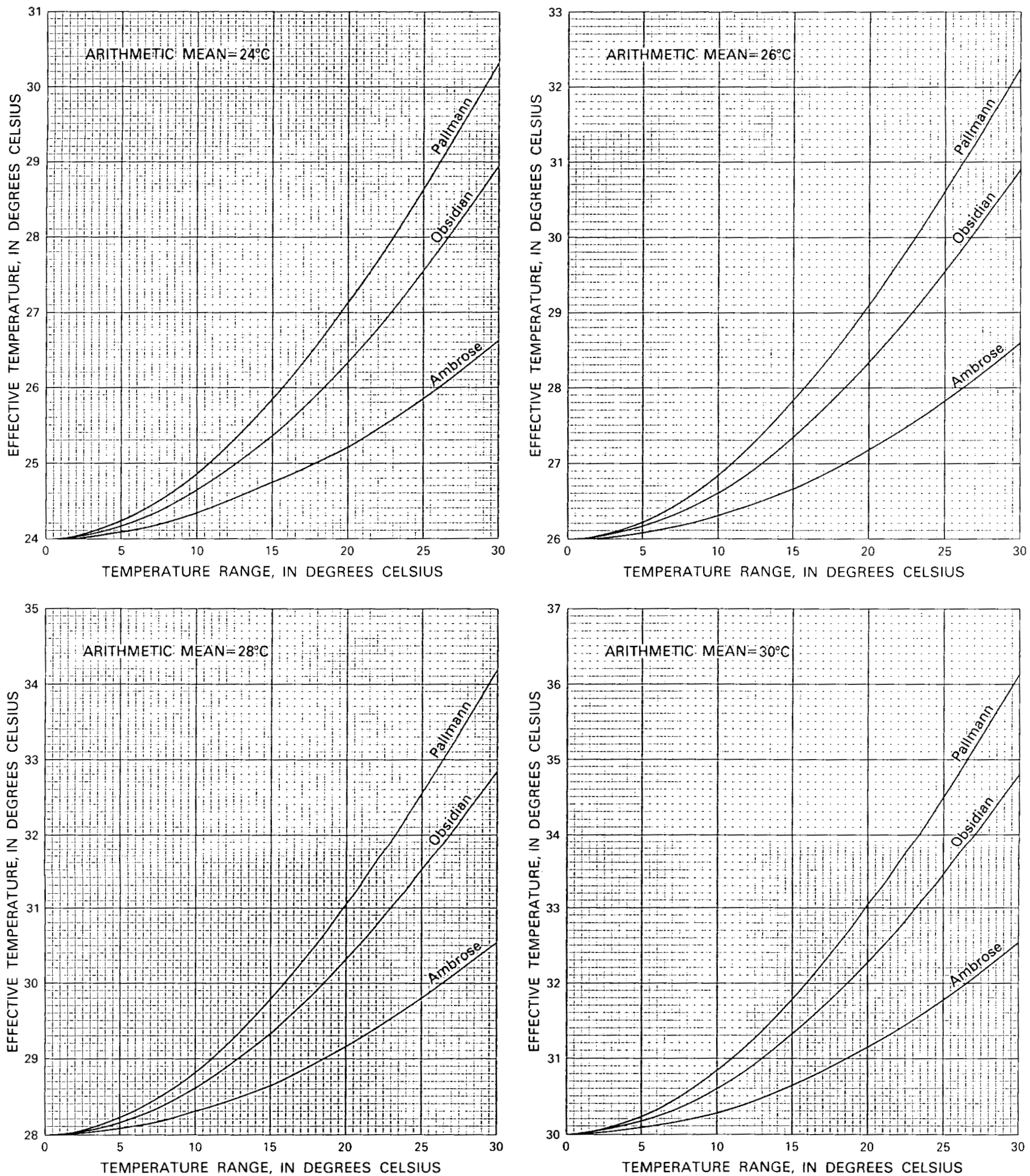

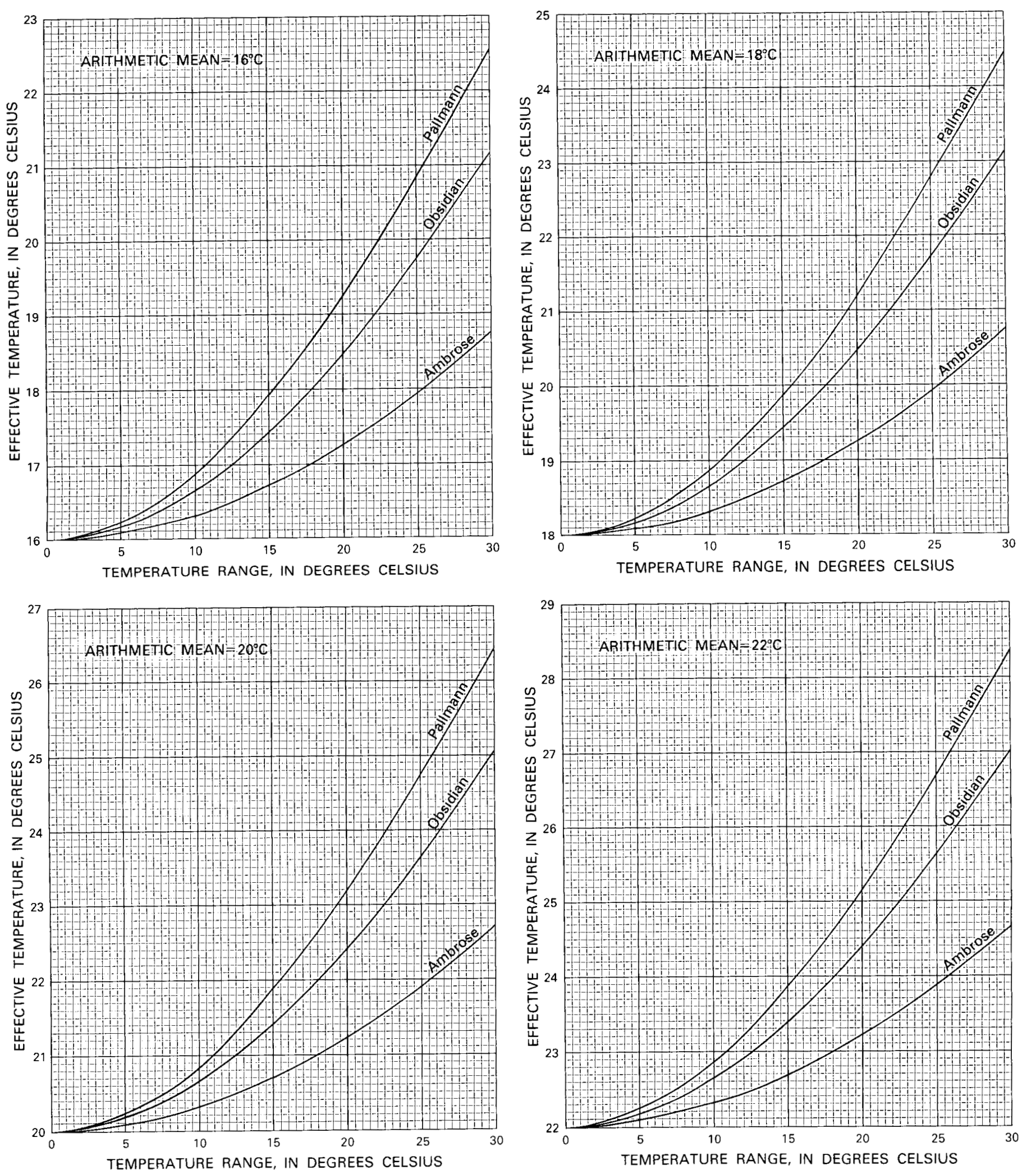
FIGURE 1
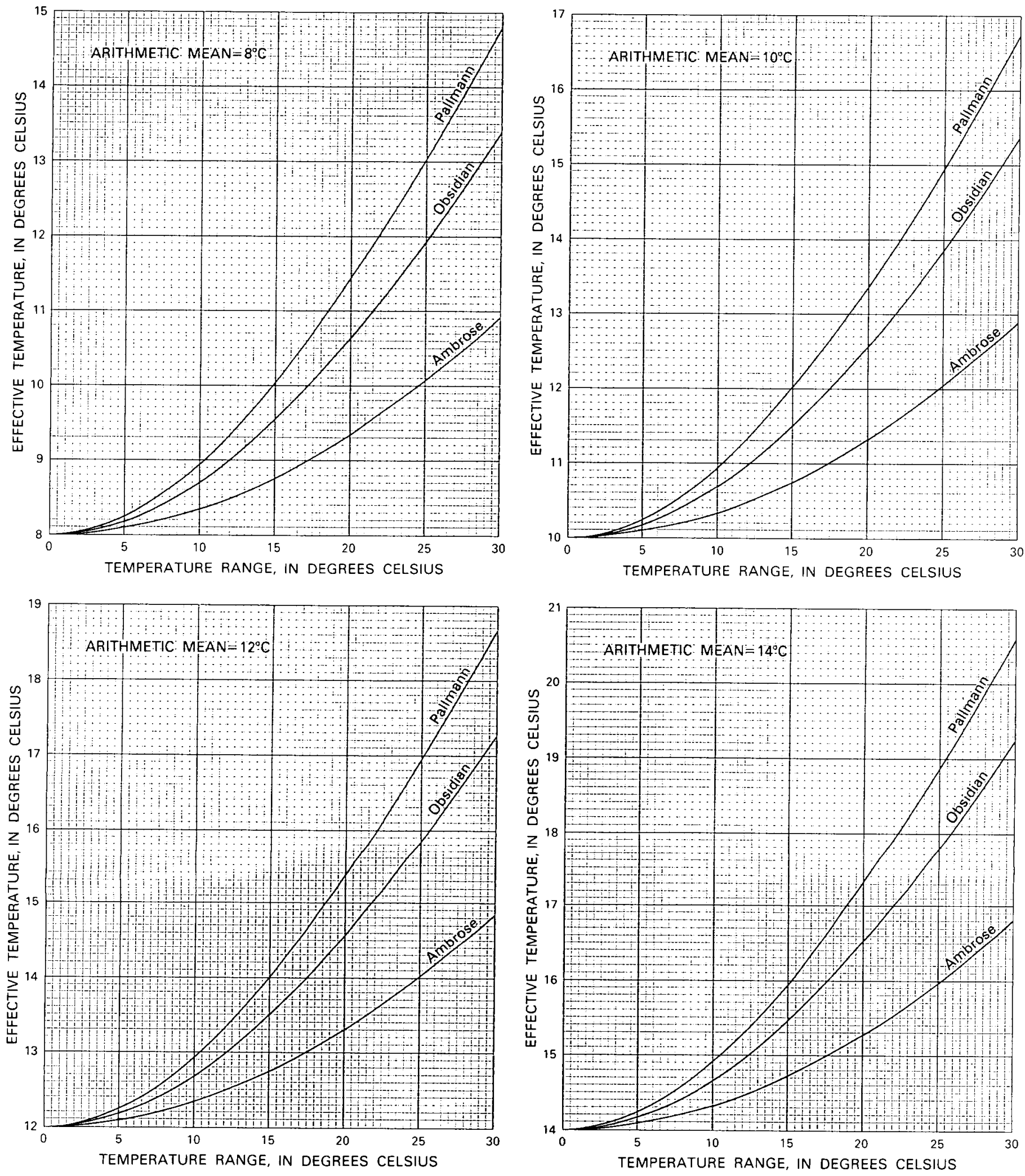



\title{
PART II, EVALUATION OF THE PALLMANN TECHNIQUE IN TWO GEOTHERMAL AREAS OF WEST-CENTRAL NEVADA
}

\author{
By F. H. Olisted, Irving Friedman; and Diniel R. NORTON
}

Abstract $\ldots \ldots \ldots \ldots \ldots$
Introduction $\ldots \ldots \ldots \ldots$
Areas selected for field tests $\ldots \ldots \ldots$

\section{ILLUSTRATIONS}

Figure 2. Map of west-central Nevada, showing the location of Soda Lakes and Upsal Hogback geothermal areas .............. 15

3. Map of Soda Lakes area, Nevada, showing measured Pallmann temperatures at 1 and $2 \mathrm{~m}$ for December $15,1976$.

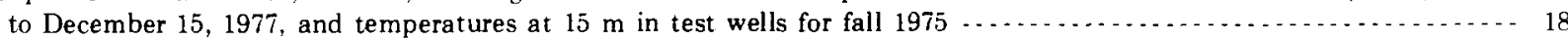

4. Diagram showing correlation of temperature at $15 \mathrm{~m}$ in test wells with measured Pallmann temperatures at $2 \mathrm{~m}$ for December 15, 1976, to December 15. 1977. Soda Lakes area, Nevada .................................. 19

5. Map of Upsal Hogback area, Nevada, showing measured Pallmann temperatures at 1 and $2 \mathrm{~m}$ for December 15, 1976, to December 15, 1977, and temperatures at $15 \mathrm{~m}$ in test wells for September $1975 \ldots \ldots \ldots$

6. Diagram showing correlation of temperature at $15 \mathrm{~m}$ in test wells with measured Pallmann temperatures at $2 \mathrm{~m}$ for December 15, 1976, to December 15. 1977. Upsal Hogback area, Nevada .

\section{TABLES}

5. Comparison of measured and adjusted Pallmann temperatures with thermistor temperatures at a depth of $1 \mathrm{~m} \ldots \ldots$

6. Comparison of coefficients of determination $\left(r^{2}\right)$ for least-mean-squares linear regressions of temperature at $15 \mathrm{~m}$ versus temperatures at $1 \mathrm{~m}$ and $2 \mathrm{~m}$

\section{ABSTRACT}

The Pallmann method, which derives an integrated temperature on the basis of the hydrolysis of sucrose to invert sugar, was tested as a means of geothermal exploration at shallow depths in two adjoining geothermal areas of west-central Nevada. Integrated Pallmann temperatures for a 12 -month period and a 3 -month, midwinter, period at depths of 1 and 2 meters $(\mathrm{m})$ are compared with temperatures at $15 \mathrm{~m}$ obtained by more conventional methods at 15 sites in the Soda Lakes area and 8 sites in the Upsal Hogback area. The field tests sug gest that the Pallmann method is useful in mapping temperature anomalies at greater depths and that the method may be superior to a conventional set of synoptic temperature measurements in outlining diffuse temperature anomalies where the areal differences in temperatures at depths of $15 \mathrm{~m}$ or more are relatively small. Better results were obtained with data obtained at a depth of $2 \mathrm{~m}$ than at $1 \mathrm{~m}$. Correlations between the Pallmann temperatures for the 3-month, midwinter, period and temperatures at $15 \mathrm{~m}$ were better than between the Pallmann temperatures for the 12 -month period and the $15-\mathrm{m}$ temperatures, probably because of the smaller difference between the Pallmann temperatures (exponential means) and the arithmetic-mean temperatures for the shorter period. 


\section{INTRODUCTION}

In principle, the utility of temperature measurements at depths of 1 or $2 \mathrm{~m}$ in geothermal exploration is enhanced if annual averages rather than single sets of synoptic values are used. Until recently, however, the determination of mean annual temperature generally has involved the use of either frequent periodic measurements with thermometer probes or buried thermometers of various types connected to expensive recording equipment. The cost advantages of many measurements at shallow depths over fewer measurements at greater depths, below the zone of annual temperature fluctuation, are therefore largely lost. Clearly, a measurement technique is needed which is more convenient and less expensive than instrumental methods and which is applicable to remote places where access is difficult.

One such technique, described by Pallmann and others (1940), derives an integrated temperature on the basis of the hydrolysis of sucrose to invert sugar. This method, hereinafter referred to for convenience as the "Pallmann method," has been tested in a variety of settings, summarized by Lee (1969), and particularly in soil-temperature measurements (O'Brien, 1971). O'Brien's results, in a small area near Schenectady, N.Y., were sufficiently encouraging that the method was tested by two of us in Yellowstone National Park (Friedman and Norton, PART III, present paper) and further tests, in a different geologic and climatic setting in west-central Nevada, seemed warranted.

In this paper we describe the results of field tests in two adjoining geothermal areas in west-central Nevada, where abundant temperature data obtained by more conventional methods at depths of $15-30 \mathrm{~m}$ are available (Olmsted and others, 1975; Olmsted, 1977).

The theory as well as laboratory and field methods are discussed in PART I, Pallmann Technique, by Norton and Friedman.

\section{AREAS SELECTED FOR FIELD TESTS}

Two areas, designated the Soda Lakes and Upsal Hogback geothermal areas, were selected for field tests of the Pallmann method. Both areas are in the west-central Carson Desert, about $100 \mathrm{~km}$ east of Reno, Nev. (fig. 2). Abundant information about the geology, hydrology, and the temperature distribution to depths of about $150 \mathrm{~m}$ was available from previous studies (Olmsted and others, 1975, p. 99-118; Olmsted, 1977).

The Soda Lakes geothermal area occupies about 21 $\mathrm{km}^{2}$ (square kilometers) between Soda Lakes to the south-southwest and Upsal Hogback to the northnortheast. Both Soda Lakes and Upsal Hogback are late Pleistocene to Holocene basaltic eruptive centers, probably alined along a concealed fault or fault system. The Soda Lakes thermal anomaly probably results from upward leakage of hot water along a steeply inclined or vertical fault-controlled conduit into shallow sand aquifers, through which the hot water moves north-northeastward, in the direction of the near-surface hydraulic gradient (Olmsted and others, 1975, p. 104). Previous data from synoptic temperature measurements at a depth of $1 \mathrm{~m}$ indicated relatively high temperatures and large heat flows in the hottest part of the thermal anomaly. Conditions seemed especially favorable for the application of the Pallmann method.

The Upsal Hogback geothermal area lies several kilometers north-northeast of the Soda Lakes area, generally east and north of Upsal Hogback. Although somewhat more extensive than the Soda Lakes geothermal area, the Upsal Hogback area is characterized by much lower near-surface temperatures and smaller heat flows. Correlation of synoptic temperatures at 1-m depth and temperatures at $30 \mathrm{~m}$ is poor, owing to the relatively small amplitude of the thermal anomaly and the relatively large perturbing effects of nongeothermal factors (Olmsted, 1977, p. B21, B24). Conditions, therefore, seemed much less favorable for application of the Pallmann method than in the Soda Lakes area. However, we hoped that the temperatures obtained with the Pallmann method at shallow depth would show a better correlation with those at greater depth than did the synoptic measurements at $1 \mathrm{~m}$ reported by Olmsted (1977).

\section{FIELD TECHNIQUES AND INSTRUMENTATION}

Most of the Pallmann samples were placed near sites of earlier U.S. Geological Survey or U.S. Bureau of Reclamation test wells, or 1-m temperature-measurement sites used by Olmsted (1977). Criteria for site selection included: (1) Level or nearly level ground; (2) absence of nearby vegetation which could shade the site for significant periods of time; (3) sufficient distance (generally at least $10 \mathrm{~m}$ ) from nearby test wells to avoid possible perturbing effects; and (4) alinement of sites along and across the long axes of the two thermal anomalies so as to check the previous interpretation (Olmsted, 1977) of the extent and configuration of the anomalies. A total of 15 sites in the Soda Lakes area and 8 sites in the Upsal Hogback area were occupied for the 1-year period from mid-December 1976, to midDecember 1977. Additional samples were placed at 19 of the 23 sites for the 3-month period from mid-December 1977, to mid-March 1978.

In order to provide data for comparison with and adjustment of some of the Pallmann-method temperatures, monthly measurements were made with a $1-m$ thermistor probe at four sites in the Soda Lakes area and four sites in the Upsal Hogback area from mid-December 1976, to mid-March 1978. Measurement techniques were those described by Olmsted (1977, p. B5). 
EVALUATION OF PALLMAN TECHNIQUE, WEST-CENTRAL NEVADA

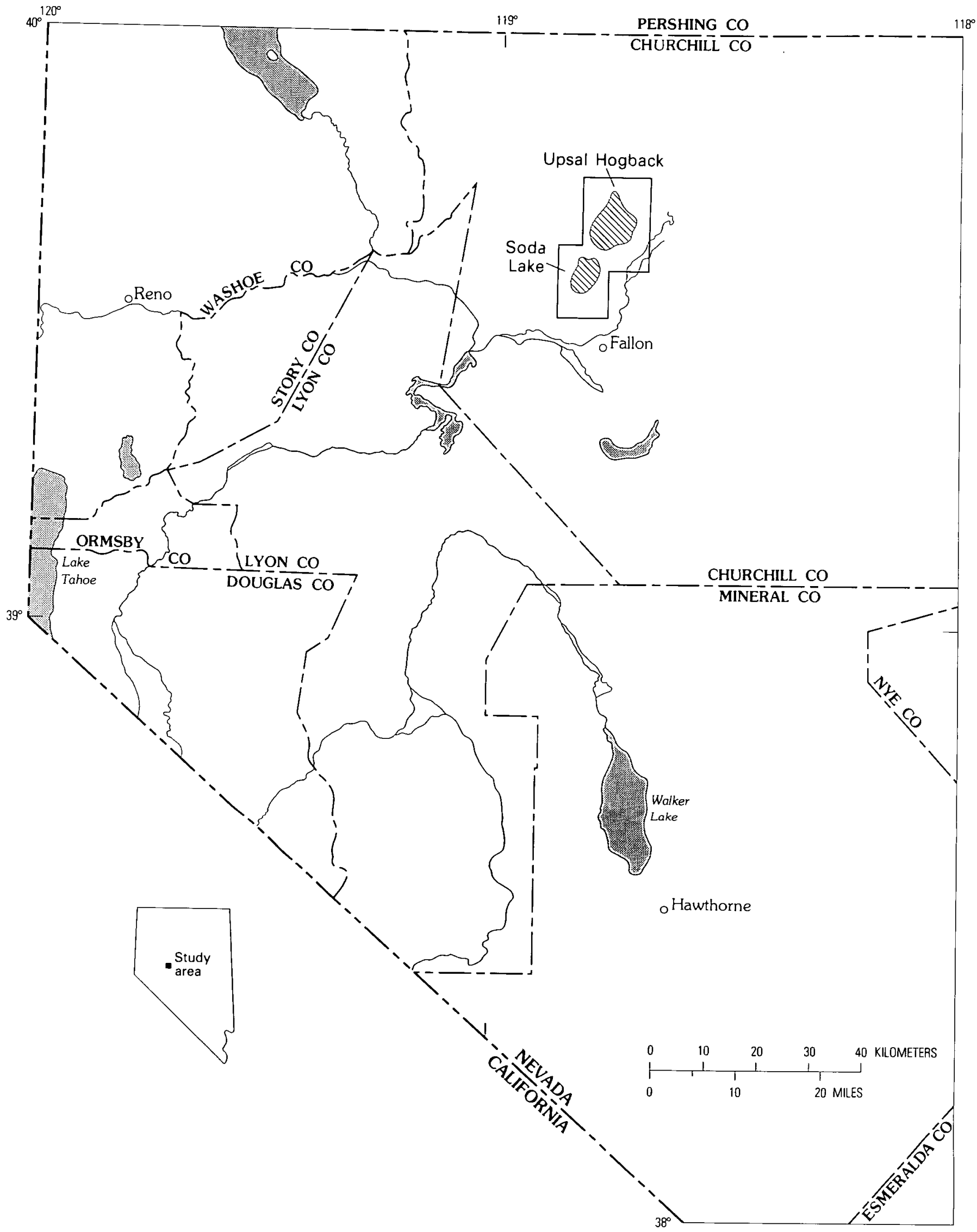

FIGURE 2.-West-central Nevada, showing the location of Soda Lakes and Upsal Hogback geothermal areas. 


\section{DATA REDUCTION AND INTERPRETATION}

Pallmann temperatures at depths of 1 and $2 \mathrm{~m}$ were determined by the method described by Norton and Friedman in PART I of the present paper. As discussed by them and by Lee (1969) and O'Brien (1971), the Pallmann method consistently overestimates integrated arithmetic-mean temperature for the period of measurement because the rate of sucrose hydrolysis varies exponentially instead of linearly with temperature. The magnitude of the difference between the measured exponential-mean temperature and the arithmeticmean temperature increases with increasing temperature range but decreases slightly with increasing mean temperatures. Lee (1969, p. 427) and Norton and Friedman (PART I, fig. 1) have calculated the corrections to the measured Pallmann temperatures, assuming harmonic temperature fluctuation for the period of interest and using an activation energy of $27 \mathrm{kcal} / \mathrm{mole}$ (kilocalories per mole) for the Pallmann reaction. The larger corrections associated with the larger ranges in temperature fluctuation account for the higher measured Pallmann temperatures at $1 \mathrm{~m}$ than at $2 \mathrm{~m}$ at many sites in the Soda Lakes and Upsal Hogback areas. Actually, at most places net heat flow for a yearly cycle is upward, and the integrated arithmetic-mean annual temperature at $1 \mathrm{~m}$ is therefore less, not greater, than that at $2 \mathrm{~m}$.

Comparisons between adjusted Pallmann temperatures-integrated arithmetic means-and means determined by thermistor measurements at monthly intervals at a depth of $1 \mathrm{~m}$ at eight sites in the Soda Lakes and Upsal Hogback areas are presented in table 5. Two periods of comparison were used: (1) The 3 months from December 15, 1977, to March 15, 1978; and (2) the 12 months from December 15, 1976, to December 15, 1977. For each of these periods the measured Pallmann temperatures were adjusted to integrated arithmeticmean temperatures, using the temperature ranges and mean temperatures measured by thermistor and the corrections given by Norton and Friedman (PART I, fig. 1). Because the Pallmann solution ampoule at $1 \mathrm{~m}$ was broken upon recovery in December 1977, at one site (72) in the Upsal Hogback area, and another site (62), in the Soda Lake area, was not reoccupied during the ensuing 3 months, only seven of the eight Pallmann sites provided temperature data for comparison with the concurrent thermistor temperatures.

For the 3 months from December 15, 1977, to March 15, 1978, the corrections to the measured Pallmann tem peratures at the seven sites were only -0.1 to $-0.3^{\circ} \mathrm{C}$ because of the relatively small temperature fluctuation for this midwinter period $\left(3 \cdot 3-5 \cdot 9^{\circ} \mathrm{C}\right)$. Except for two of
TABLE 5.-Comparison of measured and adjusted Pallmann temperatures with thermistor temperatures at a depth of $1 \mathrm{~m}$

[Leaders $(. .$.$) indicate no data]$

\begin{tabular}{|c|c|c|c|c|}
\hline \multirow{2}{*}{$\begin{array}{l}\text { Pallmann } \\
\text { site } \\
\text { number }\end{array}$} & \multicolumn{4}{|c|}{ Temperature, in degrees Celsius } \\
\hline & $\begin{array}{l}\text { Measured } \\
\text { Pallmann }\end{array}$ & $\begin{array}{l}\text { Adjusted } \\
\text { Pallmann }\end{array}$ & Thermistor & Difference' \\
\hline \multicolumn{5}{|c|}{3 months } \\
\hline $\begin{array}{l}57 \\
58\end{array}$ & $\begin{array}{r}8.8 \\
26.6\end{array}$ & $\begin{array}{r}8.6 \\
26.3\end{array}$ & $\begin{array}{r}7.9 \\
21.8\end{array}$ & $\begin{array}{l}{ }^{2} 0.7 \\
{ }^{2} 4.5\end{array}$ \\
\hline $\begin{array}{l}60 \\
72\end{array}$ & $\begin{array}{l}16.5 \\
12.7\end{array}$ & $\begin{array}{l}16.2 \\
12.5\end{array}$ & $\begin{array}{l}16.0 \\
10.7\end{array}$ & $\begin{array}{l}{ }^{3} 0.2 \\
{ }^{3} 1.8\end{array}$ \\
\hline $\begin{array}{l}73 \\
74 \\
76\end{array}$ & $\begin{array}{l}9.1 \\
9.7 \\
9.9\end{array}$ & $\begin{array}{l}9.0 \\
9.6 \\
9.7\end{array}$ & $\begin{array}{r}8.7 \\
10.1 \\
9.6\end{array}$ & $\begin{array}{c}0.3 \\
-0.5 \\
0.1\end{array}$ \\
\hline \multicolumn{5}{|c|}{12 months } \\
\hline $\begin{array}{l}57 \\
58 \\
60 \\
62 \\
73 \\
74 \\
76\end{array}$ & $\begin{array}{r}19.0 \\
>26.8 \\
23.8 \\
21.0 \\
18.5 \\
17.5 \\
18.9\end{array}$ & $\begin{array}{r}15.5 \\
>24.8 \\
22.1 \\
17.4 \\
15.7 \\
15.0 \\
16.3\end{array}$ & $\begin{array}{l}15.8 \\
26.6 \\
22.2 \\
17.4 \\
16.2 \\
15.5 \\
16.0\end{array}$ & $\begin{array}{r}-0.3 \\
-0.1 \\
-0.0 \\
0.0 \\
-0.5 \\
-0.5 \\
0.3\end{array}$ \\
\hline
\end{tabular}

'Adjusted Pallmann temperature minus thermistor temperature.

'Pallmann probe $\sim 0.5 \mathrm{~m}$ too deep; adjusted temperature probably $\sim 4^{\circ}-5^{\circ} \mathrm{C}$ too high. aPallmann probe $\sim 0.2 \mathrm{~m}$ too deep; adjusted temperature probably $\sim \mathrm{I}^{\circ} \mathrm{C}$ too high.

the sites, where the Pallmann probe was inadvertently buried about 0.5 and $0.2 \mathrm{~m}$ too deep, agreement is good between the adjusted Pallmann temperatures and the thermistor temperatures: the differences are only a few tenths of a degree Celsius.

For the preceding 12-month period, larger corrections to the measured Pallmann temperatures were required $\left(1.7^{\circ}-3.6^{\circ} \mathrm{C}\right)$ because of the larger fluctuations in temperature $\left(14.0^{\circ}-21.6^{\circ} \mathrm{C}\right)$ for this period. In spite of the larger corrections, agreement between adjusted Pallmann temperatures and thermistor temperatures is as good for the annual period as for the 3-month period.

Because of the absence of concurrent thermistor temperature measurements the temperature-fluctuation data required for calculating adjusted Pallmann temperatures were not obtained at most of the Pallmann sites. For this reason, we use measured (unadjusted) Pallmann temperatures in the following discussions of results in the two geothermal areas. As described above, these measured temperatures may be several degrees Celsius higher than the integrated arithmetic-mean temperatures, especially for longer periods such as a year and at depth of only $1 \mathrm{~m}$. However, the feasibility of the Pallmann method as a geothermal exploration tool depends in large part on the usefulness of the uncorrected temperatures in delineating areas underlain by abnormal temperatures at greater depth. 


\section{RESULTS IN SODA LAKES GEOTHERMAL AREA}

Measured Pallmann temperatures for 12 months at 1 and $2 \mathrm{~m}$ at 15 sites in the Soda Lakes area outline in a general way the thermal anomaly defined by temperatures at $15 \mathrm{~m}$ in test wells (fig. 3). Temperatures at $15 \mathrm{~m}$ range from more than $100^{\circ} \mathrm{C}$ (boiling temperatures at hydrostatic depth) in the southwest part of the anomaly to less than $20^{\circ} \mathrm{C}$ on the margins of the anomaly. The general north-northeasterly alinement of the anomaly is delineated clearly by the Pallmann temperatures, but the temperatures at $1 \mathrm{~m}$ delineate only the hottest area (more than $40^{\circ} \mathrm{C}$ at $15 \mathrm{~m}$ ). Temperatures at $1 \mathrm{~m}$ in the hottest area probably are more than $10^{\circ} \mathrm{C}$ higher than the background values, which range from less than $19^{\circ} \mathrm{C}$ to more than $18^{\circ} \mathrm{C}$.

Temperatures at $2 \mathrm{~m}$ for the same period at the same 15 sites appear to define the north-northeasterly elongation of the deeper, $15-\mathrm{m}$ anomaly somewhat better than do the 1-m temperatures. At many sites the 2-m temperatures are less than the measured 1-m temperatures for the same 12-month period because of the smaller fluctuation and correspondingly smaller negative correction at the $2-\mathrm{m}$ depth.

Correlation of temperatures at a depth of $15 \mathrm{~m}-$ below the range of significant annual temperature fluctuation-with temperatures at depths of 1 or $2 \mathrm{~m}$ affords a useful index of the reliability of the shallower measurements in outlining deeper thermal anomalies. The correlation of temperature at $15 \mathrm{~m}$ with temperature at $2 \mathrm{~m}$ measured by the Pallmann method for the 12 -month period at nine sites is shown in figure 4 . The coefficient of determination, $r^{2}$ (a measure of variance), is 0.93 , which indicates a fairly good fit to the leastmean-squares regression. Similar correlations for depths of 15 and $1 \mathrm{~m}$ and for the 3 -month period are summarized in table 2. As might be expected because of larger range in annual temperature fluctuations at $1 \mathrm{~m}$ than at $2 \mathrm{~m}$, the correlation of temperature at $15 \mathrm{~m}$ with that at $1 \mathrm{~m}$ is poorer than for $15 \mathrm{~m}$ versus $2 \mathrm{~m}\left(r^{2}=0.77\right.$ instead of 0.93 ). The similar correlations for the 3 -month period indicate a somewhat better fit (larger values of $r^{2}$ ) for these data, probably because of the smaller temperature fluctuations during the 3 -month period as compared to the 12 -month period.

\section{RESULTS IN UPSAL HOGBACK GEOTHERMAL AREA}

As shown in figure 5, the areal range in temperature at a depth of $15 \mathrm{~m}$ is only about $5^{\circ} \mathrm{C}$ in the Upsal Hogback area, as compared to a range of more than $80^{\circ} \mathrm{C}$ in the Soda Lakes area. The corresponding ranges in 12-month
Pallmann temperatures at 1 and $2 \mathrm{~m}$ are even smaller and do not correlate well with the temperatures at a greater depth. The highest temperature at $2 \mathrm{~m}\left(18.4^{\circ} \mathrm{C}\right)$ does occur at a site immediately southeast of the hottest part of the thermal anomaly at $15 \mathrm{~m}$, but the temperatures at the other Pallmann sites show no consistent pattern related to the deepter anomaly. Unfortunately, the Pallmann-solution ampoule at $1 \mathrm{~m}$ was broken upon recovery from the hottest site at $2 \mathrm{~m}$, so no pattern at all is apparent from the $1-\mathrm{m}$ data.

Coefficients of determination $\left(r^{2}\right)$ for the least-meansquares linear regressions of temperatures at $15 \mathrm{~m}$ versus temperatures at 1 and $2 \mathrm{~m}$ corroborate the generally poor correlations described above (see table 6). As in the Soda Lakes area, the temperatures at $2 \mathrm{~m}$ show a somewhat better correlation with temperatures at $15 \mathrm{~m}$ than do the temperatures at $1 \mathrm{~m}$, but the improved correlation for the $2-\mathrm{m}$ data results entirely from the single value southeast of the hottest part of the 6 thermal anomaly, where the measurement at $1 \mathrm{~m}$ was lost because of the broken Pallmann ampoule (see fig. 6). Coefficients of determination are significantly higher for the 3-month period than for the 12-month period for both 1 - and 2-m data, most likely because of the smaller amplitudes of temperature fluctuation during the shorter period.

TABLE 6.-Comparison of coefficients of determination $\left(\mathrm{r}^{2}\right)$ for leastmean-squares linear regressions of temperature at $15 \mathrm{~m}$ versus temperatures at $1 \mathrm{~m}$ and $2 \mathrm{~m}$

\begin{tabular}{|c|c|c|c|c|c|}
\hline \multirow[b]{2}{*}{$\begin{array}{l}\text { Depths } \\
\text { (m) }\end{array}$} & \multirow[b]{2}{*}{$\begin{array}{c}\text { Period } \\
\text { (months) }\end{array}$} & \multicolumn{2}{|c|}{ Soda Lakes area } & \multicolumn{2}{|c|}{ Upsal Hogback area } \\
\hline & & $\begin{array}{l}\text { No. of } \\
\text { sites }\end{array}$ & $\begin{array}{l}\text { Coefficient of } \\
\text { determination } \\
\left(r^{r}\right)\end{array}$ & $\begin{array}{c}\text { No. of } \\
\text { sites }\end{array}$ & $\begin{array}{l}\text { Coefficient of } \\
\text { determination } \\
\left(r^{3}\right)\end{array}$ \\
\hline $\begin{array}{ll}1, & 15 \\
2, & 15 \\
1, & 15 \\
2, & 15\end{array}$ & $\begin{array}{r}3 \\
3 \\
12 \\
12\end{array}$ & $\begin{array}{l}9 \\
8 \\
9 \\
9\end{array}$ & $\begin{array}{r}0.84 \\
.96 \\
.77 \\
.93\end{array}$ & $\begin{array}{l}5 \\
4 \\
4 \\
5\end{array}$ & $\begin{array}{r}0.48 \\
.58 \\
.06 \\
.38\end{array}$ \\
\hline
\end{tabular}

\section{CONCLUSIONS}

The results of our field test in the Soda Lakes and Upsal Hogback areas indicated that the Pallmann method of temperature integration, when used at depths of only 1 or $2 \mathrm{~m}$, is useful in mapping temperature anomalies at greater depths, below the range of significant seasonal temperature fluctuation. As is true of more conventional synoptic measurements, the Pallmann method works best where areal differences in temperature at greater depths are large, as in the Soda Lakes area (more than $80^{\circ} \mathrm{C}$ at $15 \mathrm{~m}$ ), and is least useful where the areal differences are small, as in the Upsal Hogback area (only about $5^{\circ} \mathrm{C}$ at $15 \mathrm{~m}$ ). 


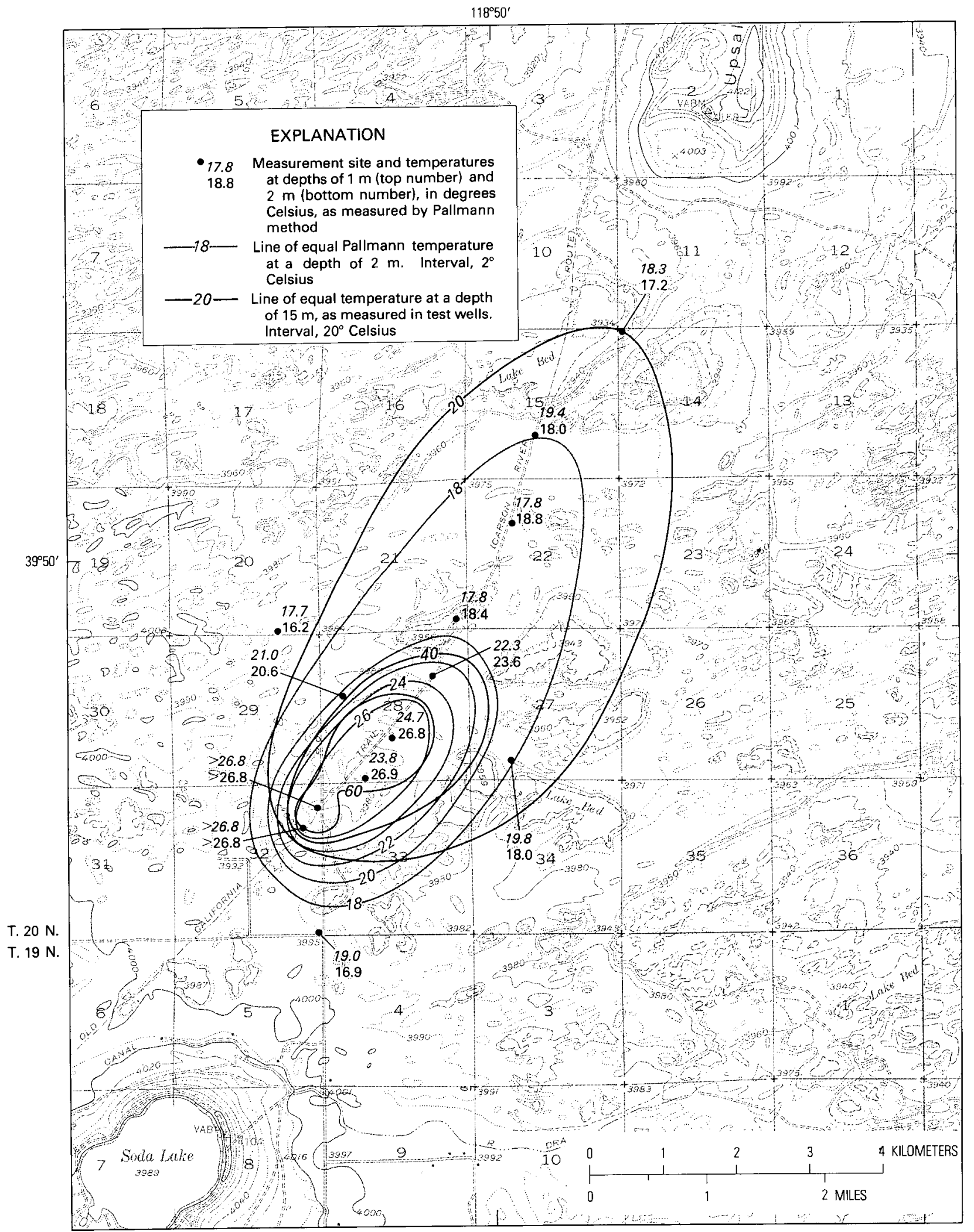

Base from USGS 15' topo series. Soda Lake, Nevada

FiguRE 3.-Soda Lakes area, Nevada, showing measured Pallmann temperatures at 1 and $2 \mathrm{~m}$ for December 15, 1976, to December 15, 1977 and temperatures at $15 \mathrm{~m}$ in test wells for fall 1975. 


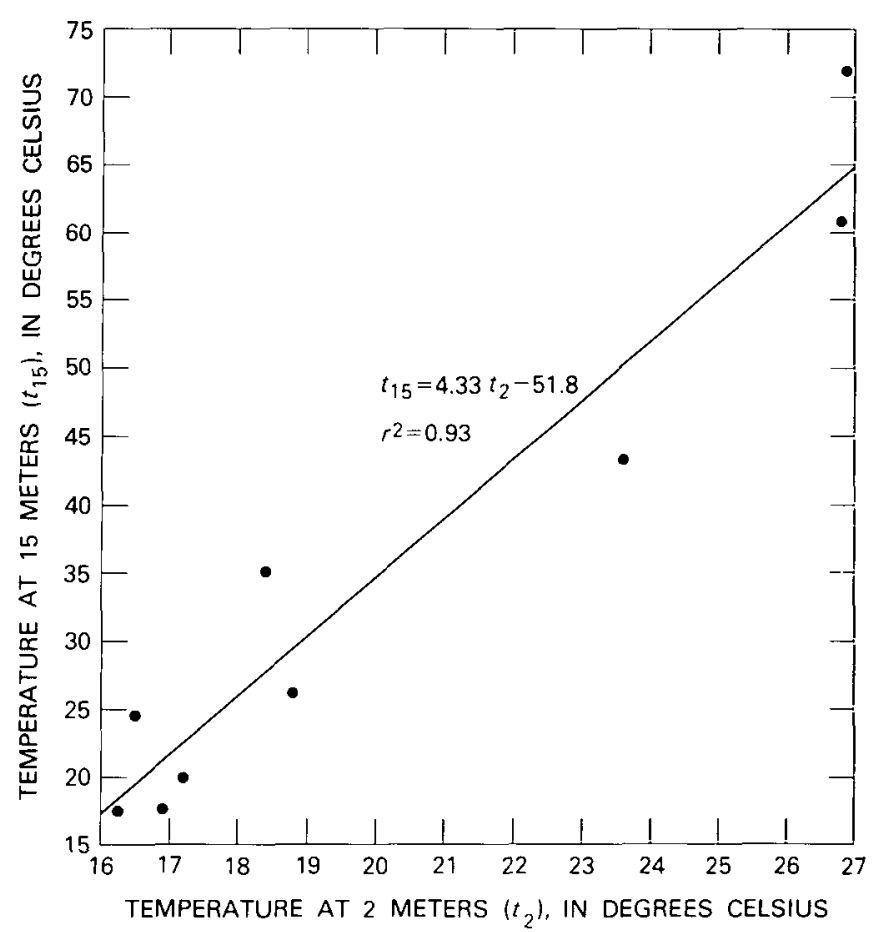

FIGURE 4.-Correlation of temperature at $15 \mathrm{~m}$ in test wells with measured Pallmann temperatures at $2 \mathrm{~m}$ for December 15, 1976, to December 15, 1977, Soda Lakes area, Nevada.

In principle, the chief advantage of the Pallmann method over single sets of synoptic temperature measurements should be in minimizing the perturbing effects of areal differences in thermal diffusivity, degree of stratification of materials, and depth to the water table. All these factors affect both the amplitude and the phase lag of the annual temperature wave but do not significantly affect the average annual temperature at a given depth, which is indicated approximately by the Pallmann temperature. The perturbing effects of the other nongeothermal factors, such as nonuniform topography, albedo, and vegetative cover, would be expected to affect both Pallmann-method and conventional synoptic-method temperature measurements equally because these factors control the average annual temperature at land surface at a site. In principle, therefore, the Pallmann method should be a better exploration tool than a single set of synoptic temperature measurements in mapping diffuse temperature anomalies like that near Upsal Hogback.

Our field test, however, suggested but did not unequivocally demonstrate the superiority of the Pallmann method over conventional synoptic measurements in the Upsal Hogback area. The coefficient of determination $\left(r^{2}\right)$ for the least-mean-squares linear regression of temperatures at $15 \mathrm{~m}$ versus temperatures at $1 \mathrm{~m}$ for the period December 15, 1977, to March 15, 1978, is 0.48 (table 6); $r^{2}$ for the equivalent regression using temperatures measured December 2, 1975, with a thermistor at $1 \mathrm{~m}$ at the same sites is only 0.20 . For the 12 -month period December 15, 1976, to December 15, $1977, r^{2}$ for temperatures at $15 \mathrm{~m}$ versus tem perature at 1 $\mathrm{m}$ by the Pallmann method is only 0.06 , but this value represents only four of the five data pairs used in the other correlations; the measurement was lost at the critical site near the hottest part of the $15-\mathrm{m}$ temperature anomaly.

In both the Soda Lakes and the Upsal Hogback areas, Pallmann temperatures at $2 \mathrm{~m}$ correlate better with temperatures at $15 \mathrm{~m}$ than do the Pallmann temperatures at $1 \mathrm{~m}$. In large part, the improved correlation is a consequence of the smaller variation, at $2 \mathrm{~m}$ than at $1 \mathrm{~m}$, in the differences between the Pallmann integratedmean temperature (an exponential mean) and the true integrated arithmetic-mean temperature. In addition, the temperatures at greater depths are affected less than are the temperatures at shallower depths by other surface and near-surface nongeothermal influences. Insofar as these influences affect the average annual temperature, a part of the advantage of deeper over shallower temperature measurements is common to both synoptic and Pallmann integrated temperatures.

Although in principle a period of a year might appear to be optimum for application of a temperatureintegration method, in our field tests the Pallmann temperatures at both 1 and $2 \mathrm{~m}$ for a 3 -month midwinter period showed a somewhat better correlation with temperatures at a greater depth than did the Pallmann temperatures for a 12-month period at the same depths. The most likely explanation involves the fact that the Pallmann temperatures are integrated exponential means rather than arithmetic means. The smaller temperature flucuation for the shorter period results in smaller difference between the Pallmann temperatures and the arithmetic-mean temperatures. This factor apparently outweighs the effects of the areal differences in the amplitude and phase lag of the annual temperature wave, which would tend to produce more scatter in the 3 -month data and a poorer correlation of these shorter term data with temperatures at $15 \mathrm{~m}$ or more.

In general, the use of the Pallmann method at depths of 1 or $2 \mathrm{~m}$ will have many of the problems common to more conventional temperature measurements at shallow depths. However, the method is convenient and it eliminates the need for the frequent visits to sites that would be required to obtain data of similar quality from sets of synoptic measurements by thermistor or thermocouple probes. 


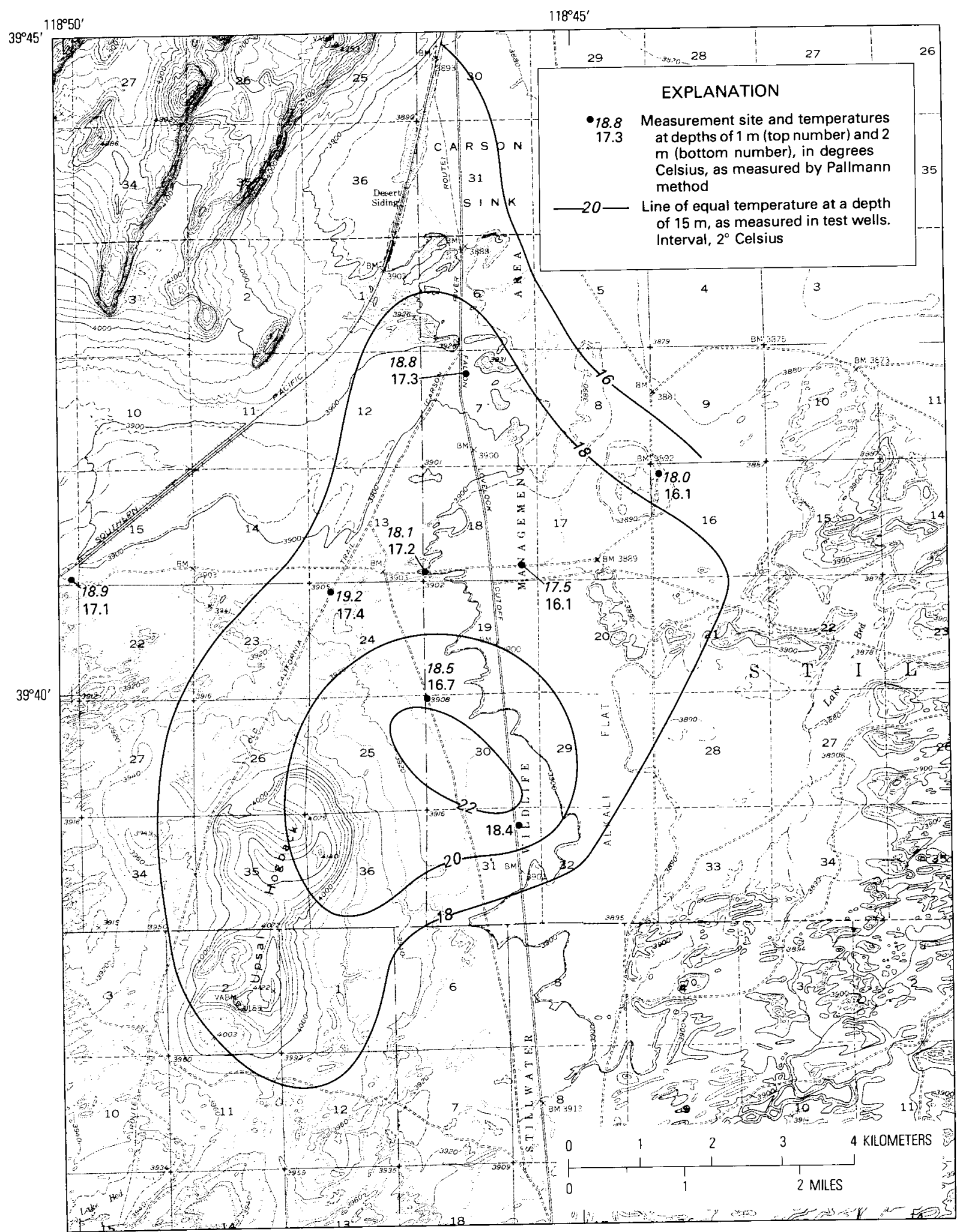

Base from USGS $15^{\prime}$ topo series.

Desert Peak, 1951: Carson Sink, 1951

Soda Lake, 1951; Stillwater, 1950.

Figure 5.-Upsal Hogback area, Nevada, showing measured Pallmann temperatures at 1 and $2 \mathrm{~m}$ for December 15, 1976, to December 15, 1977, and temperatures at $15 \mathrm{~m}$ in test wells for September 1975. 
EVALUATION OF PALLMAN TECHNIQUE, WEST-CENTRAL NEVADA

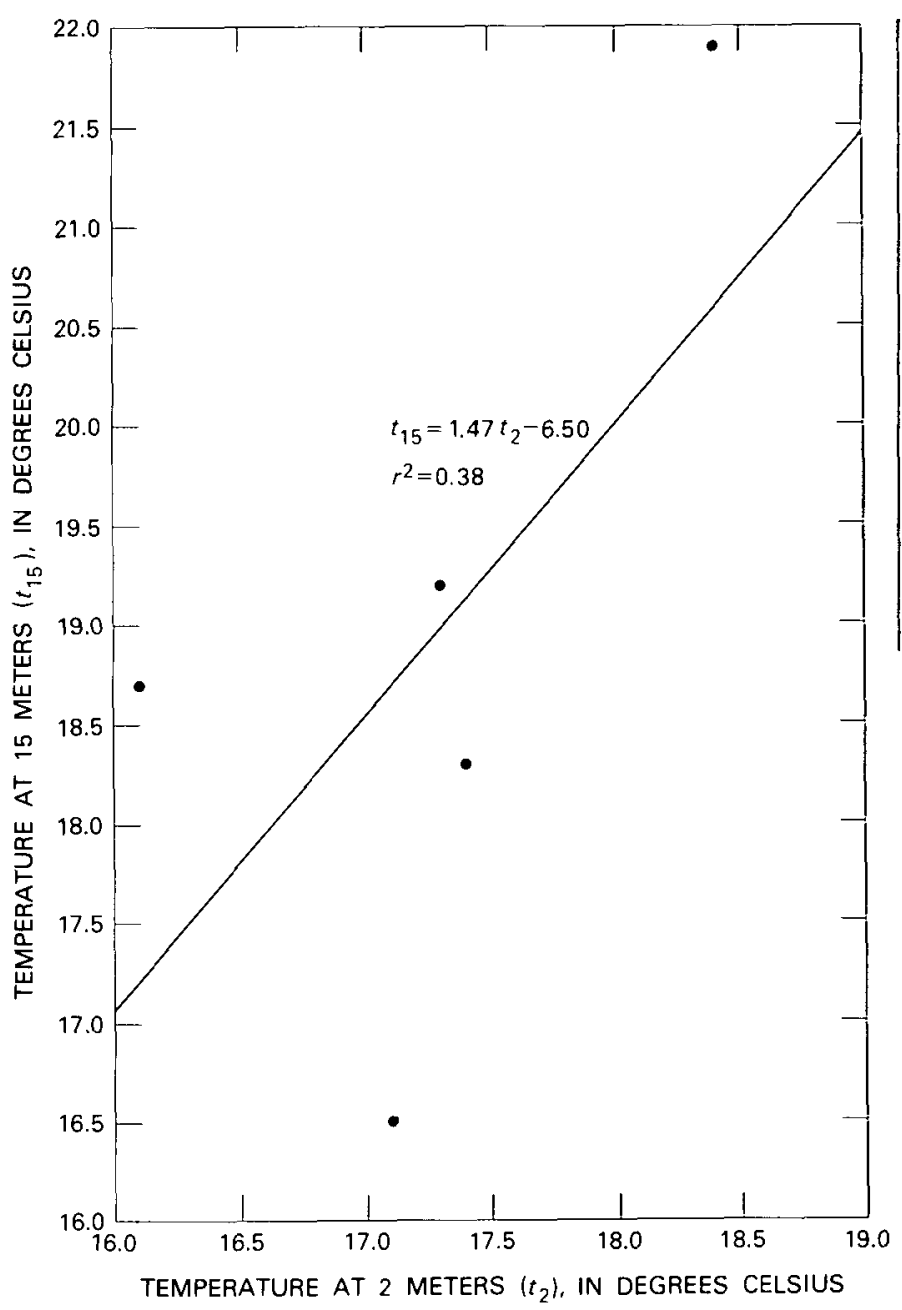

FigURE 6.-Correlation of temperature at $15 \mathrm{~m}$ in test wells with measured Pallmann temperatures at $2 \mathrm{~m}$ for December 15,1976 , to December 15, 1977, Upsal Hogback area. Nevada.

\section{REFERENCES CITED}

Lee, Richard, 1969, Chemical temperature integration: Journal of Applied Meteorology, v. 8, p. 423-430.

O'Brien, P. J., 1971, Pallmann method for mass sampling of soil, water, or air temperatures: Geological Society of America Bulletin, v. 82 , no. 10 , p. $2927-2932$.

Olmsted, F. H., 1977, Use of temperature surveys at a depth of 1 meter in geothermal exploration in Nevada: U.S. Geological Survey Professional Paper 1044-B, 25 p.

Olmsted, F. H., Glancy, P. A. Harrill, J. R., Rush, F. E., and VanDenburgh, A. S., 1975, Preliminary hydrogeologic appraisal of selected hydrothermal systems in northern and central Nevada: U.S. Geological Survey Open-file Report 75-56, 360 p.

Pallmann, H. E., Eichenberger, E., and Hasler, A., 1940, Eine neue Methode der Temperaturmessung bei okologischen oder bodenkundlichen Untersuchungen [A new method of temperature measurement in ecological or pedological investigations]: Berichte der Schweizerischen Botanischen Gesellschaft p. 337-362. 


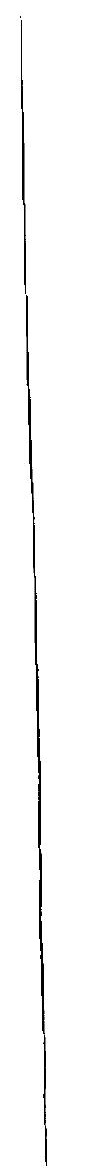


GROUND TEMPERATURE MEASUREMENTS

\title{
PART III, GROUND TEMPERATURES IN AND NEAR YELLOWSTONE NATIONAL PARK
}

\author{
By IRVING FRIEDMAN and DANIEL R. NORTON
}

\section{CONTENTS}

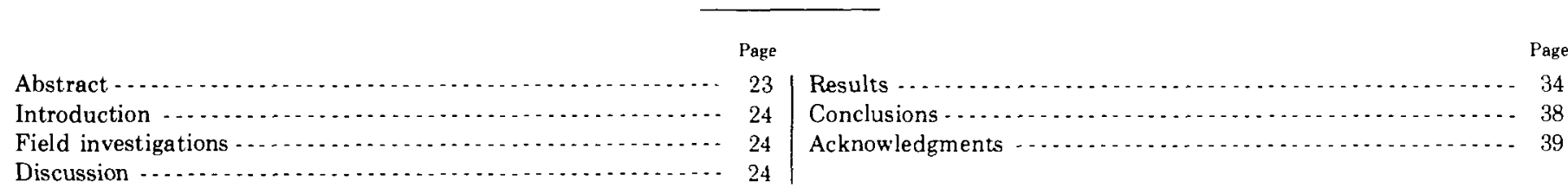

\section{ILLUSTRATIONS}

Figure, 7. Generalized sketch map of Yellowstone National Park and vicinity showing site localities and numbers -.............. 25

8. Plot of instantaneous ground-temperature measurements made in late September 1978, and mid-February 1979 ........ 32

9. Map of Yellowstone National Park and vicinity with the corrected 2-m Pallmann temperature shown for each site ........ 35

10. Plot of 2-m corrected Pallmann temperatures, arranged by types of sites . . . . . . . . . . . . . . . . . . . . . . . . 36

11. Map of Yellowstone National Park and vicinity showing temperature groups, from 0 to 6 degrees Celsius

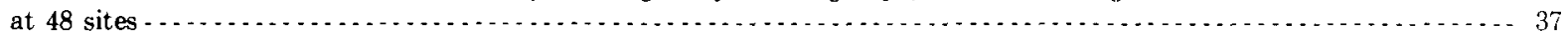

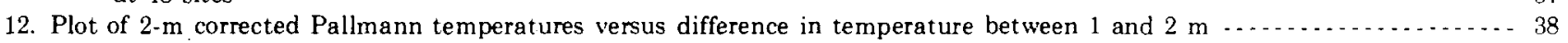

13. Plot of $2 \cdot \mathrm{m}$ instantaneous maximum temperatures made in late September 1978, and normalized to a $7000-\mathrm{ft}(2133-\mathrm{m})$ altitude

\section{TABLES}
TABLE
7. Description of sites -

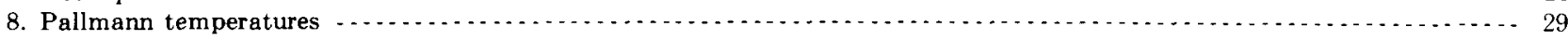
9. Instantaneous temperature measurements in degrees Celsius
29

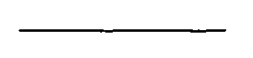

\section{ABSTRACT}

The Pallmann method was used to determine ground temperatures at 1- and 2-meter $(\mathrm{m})$ depths at 57 sites in Yellowstone National Park and vicinity for several annual periods. These measurements were used for determining rates of obsidian hydration for dating. In order to utilize these measurements for heat-flow comparisons of the different sites, the 2-m data points were normalized to a common altitude and degree of shade. Using these corrected Pallmann temperatures, we were able to define areas of anomalous heat flow at sites distant from known geothermal influence. In addition to Pallmann measurements, we made instantaneous ground-temperature measurements at most Pallmann sites at or near the temperature maximum and minimum for the year. These instantaneous measurements were made to determine the temperature range in order to convert Pallmann temperatures to arithmetic-mean annual temperatures. 


\section{INTRODUCTION}

Ground-temperature measurements were made in order to calculate rates of hydration of obsidian collected from locations in and near Yellowstone National Park. These rates of hydration were used to date volcanic flows and other geologic features containing obsidian. Our first attempt at temperature measurements utilized continuous recorders to record the temperature of thermocouples buried in the ground. This technique severely limited the location of the sites where temperature could be measured, inasmuch as electric power and a shelter had to be available for the recorder. The difficulty of servicing the equipment during the winter proved to be another limitation. The Pallmann technique seemed well suited for these measurements. In September of 1975, Irving Friedman and Daniel R. Norton, assisted by Fred Cater, emplaced forty-five 2-m probes containing Pallmann solution in various parts of the park (fig. 7). Some of the sites selected for probe emplacement were located adjacent to those places previously used to collect obsidian which was used to date volcanic flows and glacial events. Another group of probes was placed both inside and outside of the Yellowstone caldera in an attempt to determine if there was a measurable difference in ground temperature between these two areas. Previous analysis of data from obsidian-hydration measurements of $\mathrm{K}$-Ar dated obsidian flows had suggested a higher ground temperature at $2-\mathrm{m}$ depth inside of the caldera as compared with the outside. We tried to place all our probes as far as possible from known thermal areas. The probes were all emplaced in level ground. Where possible, we selected areas that would remain in the sun all day. A description of the location of the sites is given in table 7 .

\section{FIELD INVESTIGATIONS}

In September 1976, the first group of probes was removed after having been in place for 1 year, and was reemplaced with new Pallmann solutions. In addition to these initial 45 sites, 12 new sites were added in September and October of 1976. In October 1977, the Pallmann vials were retrieved from all sites and most sites were then abandoned. All the vials containing the Pallmann solution were frozen in dry ice immediately upon removal from the probe. The rotation of polarized light of the solutions were all measured within a day or two with equipment set up in the park. The results are given in table 8.

In late September and early October of 1978, instantaneous ground-temperature measurements at $0.5-, 1-$, and $2-\mathrm{m}$ depth were made at all sites. In February of 1979 , ground temperatures at these same depths were measured at a group of selected Pallmann sites. These instantaneous measurements taken in September 1978, and February 1979, at or near the maximum and minimum of the annual temperature cycle allow us to convert Pallmann-effective annual temperatures to obsidian-effective temperatures, and also to arithmeticmean annual temperatures (see PART I).

A description of the Pallmann probes and the techniques used to emplace them are given in PART I. The instantaneous temperatures were obtained using thermistor probes (Enviro Labs Model' DT101) which were allowed to remain in place until the temperature stabilized to within $0.05^{\circ} \mathrm{C}$ (Celsius) when read at 10 minute intervals. The time to reach a constant temperature was minimized by adjusting the thermistor probe to the approximate ground temperature before inserting it into the ground. In the autumn, the thermistor probes reached equilibrium within $1 / 2$ to $3 / 4$ hour.

In the winter the above procedure was modified because of temperature changes in the holes caused by penetration of cold air. To minimize this effect, the probes were inserted in the ground as soon as possible after the holes were completed. The temperature of the probes was initially adjusted to be slightly cooler than that of the ground. Upon insertion into the ground, the temperature rapidly increased to a maximum, and then began to decrease as cold air penetrated into the freshly opened soil. When this occurred, we pounded the probes about $2-4 \mathrm{~cm}$ (centimeter) farther into the ground and observed a rise in temperature as fresh warm soil was penetrated by the probe. This second maximum was recorded as the actual ground temperature. The results of these instantaneous temperature measurements are given in table 9 and plotted in figure 8 .

\section{DISCUSSION}

The annual integrated ground temperature is a function of the soil thermal diffusivities plus the:

1. Heat flow from the surface downward.

2. Heat flow from the interior upward.

The heat flow downward will be determined by the hours of sunlight, amount of shade received by the site, the type of ground cover, the albedo of the soil, the amount and duration of snow cover as well as the air temperature and wind velocity, both of which are somewhat dependent upon elevation.

If we desire to determine the effective annual temperature at a particular site for obsidian or aminoacid dating studies, then the Pallmann measurements will yield the necessary data. However, if we desire to

Use of trade name in this paper is for descriptive purposes only and does not constitute en dorsement of the product by the U.S. Geological Survey. 


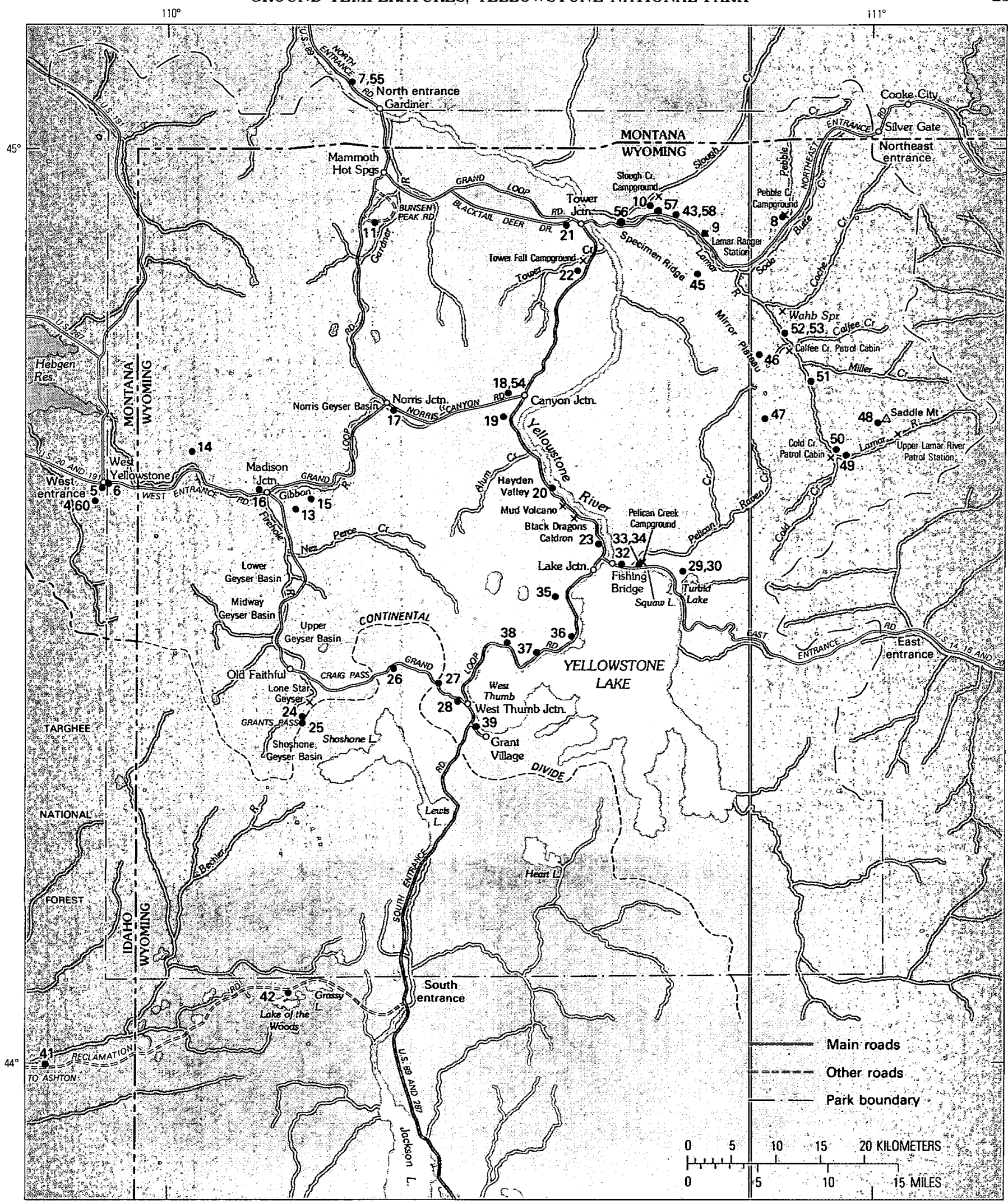

FIGURE 7.-Generalized sketch map of Yellowstone National Park and vicinity showing site localities and numbers. 


\begin{tabular}{|c|c|c|c|c|c|c|c|c|c|c|c|}
\hline \multicolumn{2}{|c|}{ Site (geographic order) } & \multirow{2}{*}{$\begin{array}{c}\text { Topographic } \\
\text { quadrangle name' }\end{array}$} & \multicolumn{3}{|c|}{ Latitude, N. } & \multicolumn{3}{|c|}{ Longitude, W. } & \multicolumn{2}{|c|}{ Altitude $^{2}$} & \multirow[b]{2}{*}{ Directions to site ${ }^{3}$} \\
\hline No. & Name & & deg & $\min$ & $\mathrm{s}$ & $\operatorname{deg}$ & $\min$ & $\bar{s}$ & ft & $\bar{m}$ & \\
\hline 1. & Teton Pass & Teton Pass $\left(7.5^{\prime}\right)$ & 43 & 29 & 31 & 110 & 57 & 17 & 8630 & 2630 & $\begin{array}{l}0.7 \mathrm{mi} \mathrm{S} \text {. on service road from } \\
\text { Teton Pass to transmission } \\
\text { tower; } 20 \text { yd W. from tower to } \\
\text { site (not shown on fig. } 7 \text { ) }\end{array}$ \\
\hline 2. & Snake River - . . & Jackson $\left(7.5^{\prime}\right)$ & 43 & 27 & 53 & 110 & 52 & 20 & 6160 & 1880 & $\begin{array}{l}2.6 \mathrm{mi} \mathrm{S} \text {. on secondary road from } \\
\text { Wilson; } 10 \text { yd E. from road } \\
\text { to site (not shown on fig. } 7 \text { ). }\end{array}$ \\
\hline 3. & Mosquito Creek ......... & Teton Pass $\left(7.5^{\prime}\right) \ldots$ & 43 & 26 & 24 & 110 & 56 & 39 & 6780 & 2065 & $\begin{array}{l}4.4 \mathrm{mi} \mathrm{S} \text {. on secondary road from } \\
\text { Wilson; } 4.5 \mathrm{mi} \text { W. on dirt road; } \\
5 \text { yd N. from road to site (not } \\
\text { shown on fig. } 7 \text { ). }\end{array}$ \\
\hline 4. & $\begin{array}{l}\text { West Yellowstone Flow - - } \\
\text { (shade). }\end{array}$ & West Yellowstone & 44 & 35 & 29 & 111 & 8 & 39 & 7540 & 2300 & $\begin{array}{l}\text { 6.6 mi S. on Madison Plateau Rd. } \\
\text { from W. Yellowstone; } 40 \mathrm{yd} \mathrm{W.} \\
\text { from road to site. }\end{array}$ \\
\hline 60. & $\begin{array}{l}\text { W. Yellowstone Flow ...... } \\
\text { (sun). }\end{array}$ & - - do & 44 & 35 & 29 & 111 & 8 & 39 & 7540 & 2300 & 15 yd E. of site 4. \\
\hline 5. & Madison Plateau Rd. ..... & $\ldots$ do $\ldots . . . . . . . .$. & 44 & 39 & 14 & 111 & 6 & 39 & 6660 & 2030 & $\begin{array}{l}0.4 \mathrm{mi} \mathrm{S} \text {. on Madison Plateau Rd. } \\
\text { from W. Yellowstone; } 15 \text { yd } \mathrm{E} \text {. } \\
\text { from road to site. }\end{array}$ \\
\hline 6. & West Entrance ................. & 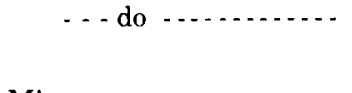 & 44 & 39 & 9 & 111 & 5 & 0 & 6660 & 2030 & $\begin{array}{l}0.3 \mathrm{miS} \text {. on service road from } \\
\mathrm{W} \text {. Entrance; } 10 \text { yd from rear } \\
\text { of pumphouse. }\end{array}$ \\
\hline 7. & Miller Garden & 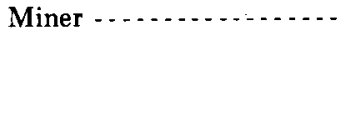 & 45 & 5 & 14 & 110 & 46 & 33 & 5120 & 1560 & $\begin{array}{l}4.9 \mathrm{mi} \mathrm{NW} \text {. on Rt. } 89 \text { from } \\
\text { Gardiner to Miller property; } \\
60 \text { yd N. of residence at end } \\
\text { of garden. }\end{array}$ \\
\hline 55. & Miller Field & - do $-\ldots . . .6$. & 45 & 4 & 40 & 110 & 46 & 34 & 5120 & 1560 & $\begin{array}{l}4.9 \mathrm{mi} \mathrm{NW} \text {. on Rt. } 89 \text { from Gardiner } \\
\text { to Miller property; } 120 \mathrm{yd} \mathrm{SW} \text {. } \\
\text { of residence to site. }\end{array}$ \\
\hline 8. & Pebble Creek & Abiathar Peak .......... & 44 & 55 & 4 & 110 & 6 & 54 & 7040 & 2145 & $\begin{array}{l}40 \mathrm{yd} \mathrm{N} \text { of parking lot of } \\
\text { Pebble Creek Campground. }\end{array}$ \\
\hline 9. & Lamar Ranger Station -. & $\ldots$ do $\ldots \ldots . . . .$. & 44 & 53 & 46 & 110 & 13 & 27 & 6740 & 2055 & $\begin{array}{l}0.4 \mathrm{mi} \mathrm{NW} \text {. on unimproved dirt } \\
\text { road from Lamar Ranger Sta- } \\
\text { tion; } 60 \mathrm{yd} \text { W. from road to site. }\end{array}$ \\
\hline 10. & Slough Creek & Tower Junction - . . . . . . . . . & 44 & 45 & 35 & 110 & 18 & 58 & 6220 & 1895 & $\begin{array}{l}0.4 \mathrm{mi} \mathrm{N} \text {. on Slough Creek Camp- } \\
\text { ground road from its inter- } \\
\text { section with NE. Entrance } \\
\text { road; } 10 \text { yd E. from road to site. }\end{array}$ \\
\hline 11. & Bunsen Peak & Mammoth ......... & 44 & 55 & 28 & 110 & 43 & 21 & 7280 & 2220 & $\begin{array}{l}0.6 \text { mi S. on Bunsen Peak Rd., } \\
\text { from its intersection with } \\
\text { Grand Loop Rd.; original site } \\
\text { No. } 11,4 \text { yd SW. from road; site } \\
\text { Nos. } 11 \mathrm{a}, \mathrm{b}, \mathrm{c} \text {, and d, } 13 \text { yd SW. } \\
\text { from road. }\end{array}$ \\
\hline 13. & Mesa Road I & -Madison Junction - & 44 & 37 & 11 & 110 & 49 & 42 & 7180 & 2190 & $\begin{array}{l}\text { 1.3 mi E. on Mesa Rd. from its } \\
\text { intersection with Grand Loop } \\
\text { Rd.; } 10 \text { yd S. from road to } \\
\text { site. }\end{array}$ \\
\hline 14. & Cougar Creek ............. & $-\cdots$ do $-\ldots$ & 44 & 40 & 49 & 110 & 57 & 57 & 6900 & 2105 & $\begin{array}{l}1.5 \mathrm{mi} \mathrm{NW} \text {. on trail starting } \\
\text { from } \mathrm{E} \text {. side of bridge crossing } \\
\text { Madison } \mathrm{R} \text {. at a point } 7.4 \mathrm{mi} \\
\mathrm{E} \text {. of the } \mathrm{W} \text {. Entrance on } \mathrm{W} \text {. } \\
\text { Entrance Rd.; } 10 \text { yd } \mathrm{N} .80^{\circ} \mathrm{E} \text {. } \\
\text { from trail-marker sign to site. }\end{array}$ \\
\hline 15. & Mesa Road II .............. & - - do - & 44 & 38 & 20 & 110 & 48 & 15 & 7180 & 2190 & $\begin{array}{l}\text { 3.1 mi E. and NE. on Mesa Rd. } \\
\text { from its intersection with } \\
\text { Grand Loop Rd.; } 5 \text { yd E. from } \\
\text { road to site. }\end{array}$ \\
\hline 16. & Harlequin Lake ............. & $\ldots$ do $\ldots$ & 44 & 38 & 27 & 110 & 53 & 30 & 6800 & 2075 & $\begin{array}{l}11.7 \mathrm{mi} \mathrm{E.on} \mathrm{W.} \mathrm{Entrance} \mathrm{Rd.} \\
\text { from W. Entrance; } 30 \mathrm{yd} \mathrm{N} \text {. } \\
\text { from road to site. }\end{array}$ \\
\hline 17. & Norris Junction - & Norris Junction - . . . . . . & 44 & 43 & 30 & 110 & 40 & 54 & 7500 & 2285 & $\begin{array}{l}0.8 \mathrm{mi} \mathrm{W} \text {. on Norris-Canyon Rd. } \\
\text { from Norris Jct.; } 50 \text { yd. S. from } \\
\text { road to site. }\end{array}$ \\
\hline 18. & 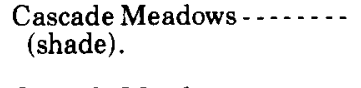 & $\ldots$ do $\ldots \ldots$ & 44 & 44 & 7 & 110 & 30 & 57 & 7950 & 2425 & $\begin{array}{l}1.2 \mathrm{mi} \text { E. on Norris-Canyon } \mathrm{Rd} \text {. } \\
\text { from Canyon Jct.; } 40 \mathrm{yd} . \mathrm{N} \text {. } \\
\text { from road to site. }\end{array}$ \\
\hline 54. & $\begin{array}{l}\text { Cascade Meadows ......... } \\
\text { (sun). }\end{array}$ & $\ldots$ do $-\ldots$ & 44 & 44 & 7 & 110 & 30 & 46 & 7880 & 2400 & $\begin{array}{l}1.1 \mathrm{mi} \mathrm{W} \text {. on Norris-Canyon } \mathrm{Rd} \text {. } \\
\text { from Canyon Jct.; } 20 \mathrm{yd} \mathrm{N} \text {. from } \\
\text { road to site. }\end{array}$ \\
\hline 19. & Upper Falls & $\cdots$ do $\ldots \ldots$ & 44 & 42 & 57 & 110 & 30 & 57 & 7960 & 2425 & $\begin{array}{l}0.6 \mathrm{mi} \text { W. on service road from } \\
\text { its intersection with Grand } \\
\text { Loop Rd.; } 40 \text { yd S. from road } \\
\text { to site. }\end{array}$ \\
\hline
\end{tabular}


TABLE 7.-Description of sites-continued

\begin{tabular}{|c|c|c|c|c|c|c|c|c|c|}
\hline \multicolumn{2}{|c|}{ Site (geographic order) } & \multirow{2}{*}{$\begin{array}{c}\text { Topographic } \\
\text { quadrangle name' }\end{array}$} & \multicolumn{3}{|c|}{ Latitude. ミs. } & \multicolumn{3}{|c|}{ Longitude. W. } & \multirow{2}{*}{ Alti } \\
\hline No. & Name & & $\operatorname{deg}$ & $\min$ & $s$ & deg & $\min$ & $\bar{s}$ & \\
\hline 20 . & Elk Antler Creek & 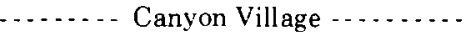 & 44 & 38 & 18 & 110 & 26 & 59 & 7720 \\
\hline 21. & Blacktail Deer Dr & . . . . . . Tower Junction - ....... . . & 44 & 55 & 36 & 110 & 27 & 19 & 6840 \\
\hline 22. & Tower Fall ...... & $\ldots$ do $\ldots \ldots . . .$. & 44 & 51 & 56 & 110 & 23 & 37 & 7080 \\
\hline 23. & LeHardys Rapids & ...... Canyon Village ........ & 44 & 36 & 15 & 110 & 23 & 0 & 7800 \\
\hline 24. & Grants Pass I .... & $\ldots \ldots . . . . . . . . . .$. & 44 & 23 & 17 & 110 & 49 & 53 & 7900 \\
\hline 25. & Grants Pass II - - & $\ldots$ do $\ldots . . . . .$. & 44 & 22 & 56 & 110 & 49 & 36 & 8000 \\
\hline
\end{tabular}

26. DeLacy Creek $\ldots . . . \ldots .$. West Thumb ......... $44 \quad 27$

27. Divide Lake .......... $\quad \ldots$ do $\ldots \ldots \ldots$...... $44 \quad 26$

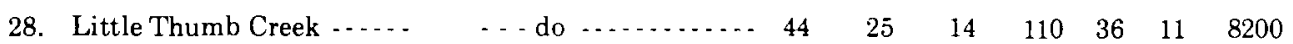

29. Turbid Lake (shade). . . . . Canyon Village . . . . . . . . $44 \quad 34 \quad 33 \quad 7 \quad \begin{array}{lllllll}110 & 16 & 1 & 7920\end{array}$

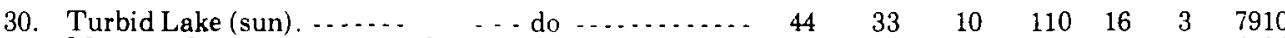

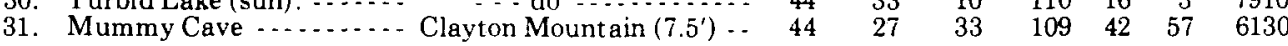

32. Fishing Bridge ........... . Canyon Village ........ . $44 \quad 33 \quad 42 \quad 110 \quad 21 \quad 49 \quad 7780$

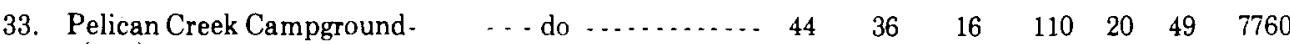
(sun).

34. Pelican Creek Campground (shade).

35. Natural Bridge

36. Sand Point

Frank Island

West'Thumb

37. Pumice Point

38. Arnica Creek

39. Grant Village

$$
\begin{gathered}
\ldots \text { do } \\
\ldots \text { do }
\end{gathered}
$$$$
\cdots
$$

41. Falls River
Warm River Butte

\section{$m$}

Directions to site $\mathrm{e}^{\mathrm{j}}$

$23558.4 \mathrm{mi} \mathrm{S}$. on Grand Loop Rd. from Canyon Jct.; 70 yd NW. from road to site.

$20850.6 \mathrm{mi} \mathrm{W}$. on Blacktail Deer Dr. from its eastern intersection with Grand Loop Rd.; 20 yd S. from road to site.

$21602.3 \mathrm{mi} \mathrm{S}$. on Grand Loop Rd. from its intersection with Tower Falls Campground; 40 yd W. from road to site.

$23752.6 \mathrm{mi} \mathrm{N}$. on Grand Loop Rd. from Lake Jct.; 50 yd W. from road to site.

$24102.4 \mathrm{miS}$. on trail from footbridge over the Firehole R. located near Lone Star geyser; 10 yd $W$. from trail to site.

$24402.9 \mathrm{mi} \mathrm{S}$. on trail from footbridge over the Firehole $\mathrm{R}$. located near Lone Star geyser; 5 yd SW. of trail to site at Continental Divide.

$24407.9 \mathrm{mi} \mathrm{W}$. on Grand Loop Rd. from W. Thumb Jct.; 30 yd SW. from road to site.

$25554.1 \mathrm{mi}$ W. on Grand Loop Rd. from $W$. Thumb Jct.; 10 yd $N$. of road to site.

$25002.1 \mathrm{mi} \mathrm{W}$. on Grand Loop Rd. from W. Thumb Jct.; 20 yd SW. from road site.

$24153.0 \mathrm{mi}$ E. on service road from its intersection with E. Entrance Rd. at Squaw Lake; 15 yd NE. from road to site ( 22 yd $\mathrm{SE}$. of site No. 30).

$241020 \mathrm{yd}$ NW. of site No. 29

$186817.4 \mathrm{mi} \mathrm{E}$. on Wyoming Rt. 16 from E. Entrance; 15 yd SE. from road to site. (not:shown on fig. 7).

$23701.0 \mathrm{mi}$ E. on E. Entrance Rd. from Fishing Bridge; 10 yd $N$. from road to site.

$23650.4 \mathrm{mi} \mathrm{N}$. on Pelican Creek Campground road from its intersection with E. Entrance Rd.; $15 \mathrm{yd} W$. of parking turnout.

$23650.4 \mathrm{mi} \mathrm{N}$. on Pelican Creek Campground road from its intersection with E. Entrance Rd.; $5 \mathrm{yd}$ E. of parking turnout.

$23850.7 \mathrm{mi} \mathrm{W}$. on Natural Bridge road from its intersection with Grand Loop Rd.; 25 yd N. from road to site.

$24003.6 \mathrm{mi} \mathrm{S}$. on Grand Loop Rd. from its intersection with Natural Bridge road; 35 yd NW. from road to site.

$23659.9 \mathrm{mi} \mathrm{N}$. on Grand Loop Rd. from W. Thumb Jct.; 10 yd NW. from road to site.

$23655.8 \mathrm{mi} \mathrm{N}$. on Grand Loop Rd. from $W$. Thumb Jet.; $30 \mathrm{yd}$ $N$. from road to site.

$2390 \quad 0.2 \mathrm{mi} \mathrm{E}$. on Grant Village road from its intersection with $\mathrm{S}$. Entrance Rd.; 15 yd N. from road to site.

$18100.3 \mathrm{mi}$ E. on Reclamation Rd. from Targhee National Forest boundary; 10 yd NE. from road to site. 
TABLE 7.-Description of sites-continued

\begin{tabular}{|c|c|c|c|c|c|c|c|c|c|c|c|}
\hline \multicolumn{2}{|c|}{ Site (geographic order) } & \multirow{2}{*}{$\begin{array}{c}\text { Topographic } \\
\text { quadrangle name' }\end{array}$} & \multicolumn{3}{|c|}{ Latitude, $N$. } & \multicolumn{3}{|c|}{ Longitude, $W$} & \multicolumn{2}{|c|}{ Altitude $^{2}$} & \multirow[b]{2}{*}{ Directions to site ${ }^{3}$} \\
\hline No. & Name & & $\operatorname{deg}$ & $\min$ & $\mathrm{s}$ & deg & $\min$ & $\overline{\mathrm{s}}$ & $\mathrm{ft}$ & $\overline{\mathrm{m}}$ & \\
\hline 42. & Grassy Lake ................... & Grassy Lake Reservior .... & 44 & 7 & 34 & 110 & 50 & 35 & 7300 & 2225 & $\begin{array}{l}1.1 \mathrm{mi} \text { W. on Reclamation Rd. } \\
\text { from the W. end of the Grassy } \\
\text { Lake Dam; } 5 \text { yd SW. from road } \\
\text { to site. }\end{array}$ \\
\hline 43. & Lamar Canyon East I . . ... & Tower Junction -... & 44 & 54 & 53 & 110 & 15 & 49 & 6560 & 2000 & $\begin{array}{l}2.6 \mathrm{mi} \mathrm{E} \text {. on NE. Entrance Rd. } \\
\text { from its intersection with } \\
\text { Slough Creek Campground } \\
\text { road; } 20 \text { yd N. from road to site. }\end{array}$ \\
\hline 58. & Lamar Canyon East II .... & $\ldots$ do $\ldots \ldots \ldots$ & 44 & 54 & 53 & 110 & 15 & 49 & 6560 & 2000 & $\begin{array}{l}10 \text { yd E. of site No. } 43 \text { to } \\
\text { site No. } 58\end{array}$ \\
\hline 45. & Fossil Forest .............. & Abiathar Peak & 44 & 51 & 28 & 110 & 14 & 20 & 8400 & 2560 & $\begin{array}{l}\text { 2.7 air miles } \mathrm{S} .4^{\circ} 12^{\prime} \mathrm{W} \text {. from } \\
\text { Lamar Ranger Station; } 15 \mathrm{yd} \\
\text { SW. from edge of forest. }\end{array}$ \\
\hline 46. & Flint Creek .................. & $\ldots$ do $\ldots \ldots . .$. & 44 & 46 & 5 & 110 & 10 & 15 & 9025 & 2750 & $\begin{array}{l}2.9 \text { air miles } S .77^{\circ} 48^{\prime} \mathrm{W} \text {. from } \\
\text { Calfee Creek Patrol Cabin; } 180 \\
\text { yd N. of Flint Creek tributary. }\end{array}$ \\
\hline 47. & Timothy Creek & Pelican Cone........ & 44 & 42 & 54 & 110 & 9 & 47 & 8520 & 2595 & $\begin{array}{l}\text { 5.5 air miles } \mathrm{N} .67^{\circ} 0^{\prime} \mathrm{W} \text {. from } \\
\text { Cold Creek Patrol Cabin; } 30 \\
\text { yd. E. from buffalo wallow. }\end{array}$ \\
\hline 48. & Saddle Mountain ......... & Sunlight Peak $\ldots$ & 44 & 42 & 6 & 110 & 59 & 31 & 9820 & 2995 & $\begin{array}{l}\text { 2.1 air miles N. } 63^{\circ} 30^{\prime} \mathrm{W} \text {. from } \\
\text { Upper Lamar R. Ranger } \\
\text { Station; } 70 \text { yd S. from saddle } \\
\text { between Little Saddle Moun- } \\
\text { tain and Hayne Mountain. }\end{array}$ \\
\hline 49. & Little Lamar River ....... . & Pelican Cone & 44 & 40 & 20 & 110 & 1 & 32 & 7440 & 2270 & $\begin{array}{l}1.8 \text { air miles N. } 66^{\circ} 0^{\prime} \mathrm{W} \text {. from Cold } \\
\text { Creek Patrol Cabin; } 25 \mathrm{yd} \mathrm{NE.} \\
\text { from edge of forest. }\end{array}$ \\
\hline 50. & Cold Creek & $\cdots$ do & 44 & 41 & 0 & 110 & 3 & 22 & 7250 & 2210 & $\begin{array}{l}0.2 \text { air miles E. from Cold Creek } \\
\text { Patrol Cabin to forest edge; } 20 \\
\text { yd E. from forest edge to site. }\end{array}$ \\
\hline 51. & Miller Creek ............ & Abiathar Peak ........... & 44 & 45 & 16 & 110 & 5 & 51 & 7160 & 2180 & $\begin{array}{l}1.8 \text { air miles } \mathrm{S} .27^{\circ} 36^{\prime} \mathrm{E} \text {. from } \\
\text { Calfee Creek Patrol Cabin. }\end{array}$ \\
\hline 52. & Cache Creek (sun) ....... & $\ldots$ do $\ldots . . . . . . .$. & 44 & 47 & 59 & 110 & 7 & 38 & 6870 & 2095 & $\begin{array}{l}\text { 1.6 air miles N. } 26^{\circ} 24^{\prime} \mathrm{W} \text {. from } \\
\text { Calfee Creek Patrol Cabin to } \\
\text { campsite } 34 \text { signpost; } 40 \text { yd } \\
\text { NE. from signpost to site. }\end{array}$ \\
\hline 53. & Cache Creek (shade) ...... & $\ldots$ do $\ldots . . .$. & 44 & 47 & 59 & 110 & 7 & 38 & 6870 & 2095 & $\begin{array}{l}30 \text { yd E. from site No. } 52 \text { to } \\
\text { site No. } 53 \text {. }\end{array}$ \\
\hline 56. & Gravel Pit $\ldots \ldots$ & Tower Junction - ......... & 44 & 54 & 28 & 110 & 20 & 46 & 6180 & 1885 & $\begin{array}{l}4.2 \mathrm{mi} \text { E. on NE. Entrance Rd. } \\
\text { from Tower Jct.; } 20 \text { yd N. } \\
\text { from road to site. }\end{array}$ \\
\hline 57. & Lamar Canyon West...... & $\ldots$ do $\ldots \ldots$ & 44 & 55 & 13 & 110 & 18 & 12 & 6360 & 1940 & $\begin{array}{l}\text { 6.6 mi E. on NE. Entrance Rd. } \\
\text { from Tower Jct.; } 15 \text { yd N. } \\
\text { from road to site. }\end{array}$ \\
\hline 59. & Ashton & Warm River $\left(7.5^{\prime}\right)$ & 44 & 4 & 19 & 111 & 21 & 16 & 5565 & 1695 & $\begin{array}{l}6.3 \mathrm{mi} \text { E. on Rt. } 67 \text { from Ashton } \\
\text { to junction with Reclamation } \\
\text { Rd.; site is in northerly part } \\
\text { of triangular junction, } 5 \text { yd } \\
\text { from Reclamation Rd. (not } \\
\text { shown on fig. } 7 \text { ). }\end{array}$ \\
\hline
\end{tabular}

All quadrangles are 15 minute unless otherwise noted.

${ }^{2}$ Altitudes given to $\pm 20 \mathrm{ft}$ and $\pm 5 \mathrm{~m}$.

'Odometer mileage; paced yards. A 1-yd pace equals about $1 \mathrm{~m}$. 
TABLE 8.-Pallmann temperatures

[t. temperature; $\Delta t$, difference in temperature between $1 \cdot m$ and $2 \cdot m$ values: leaders $(\ldots)$ indicate no data]

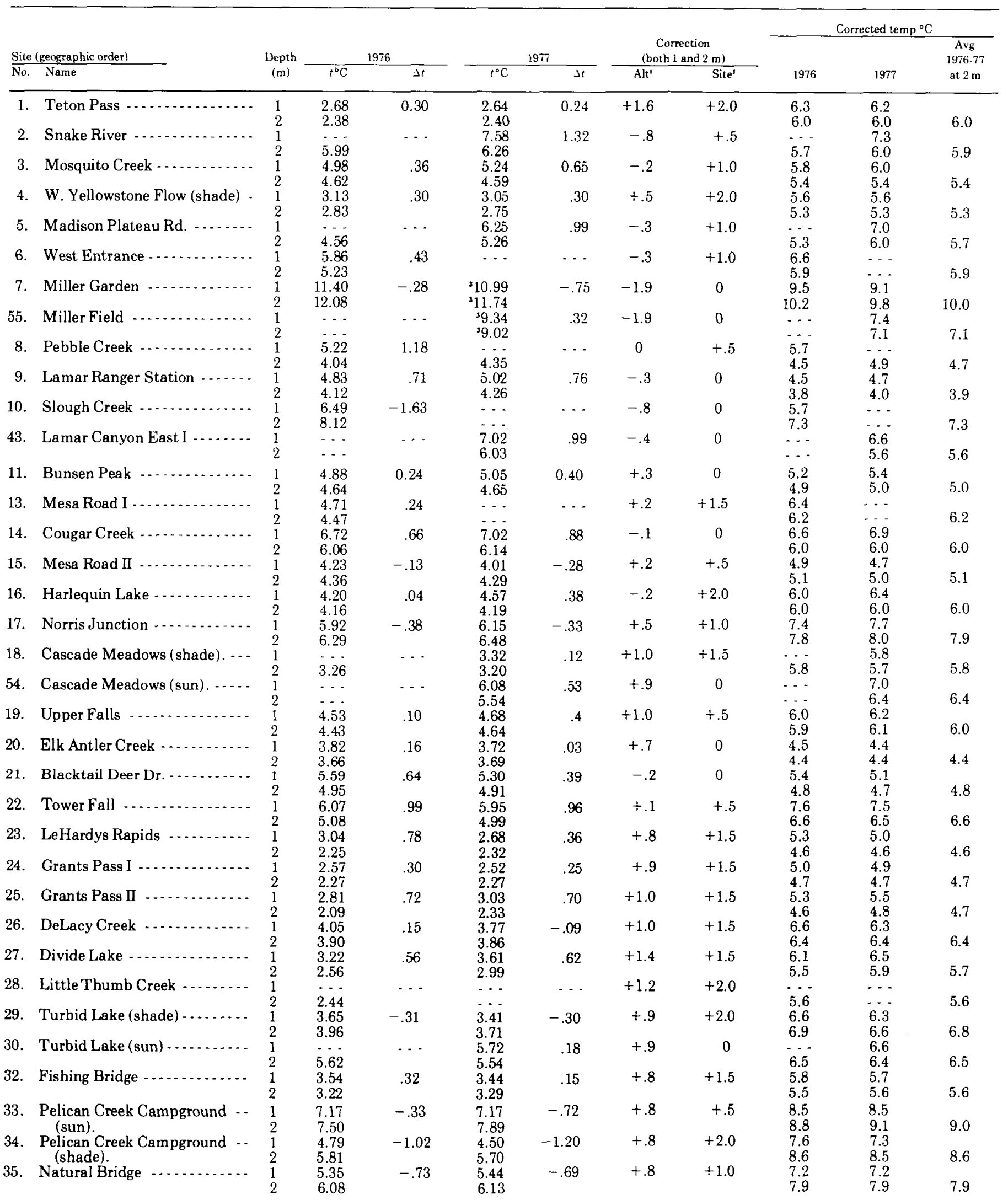


T ABLE 8.-Pallmann temperatures-continued

\begin{tabular}{|c|c|c|c|c|c|c|c|c|c|c|c|}
\hline \multirow{3}{*}{\multicolumn{2}{|c|}{$\frac{\text { Site (geographic order) }}{\text { No. Name }}$}} & \multirow{3}{*}{$\begin{array}{c}\text { Depth } \\
(\mathrm{m})\end{array}$} & \multirow{2}{*}{\multicolumn{2}{|c|}{1976}} & \multirow{2}{*}{\multicolumn{2}{|c|}{1977}} & \multirow{2}{*}{\multicolumn{2}{|c|}{$\begin{array}{c}\text { Correction } \\
\text { (both } 1 \text { and } 2 \mathrm{~m} \text { ) }\end{array}$}} & \multicolumn{3}{|c|}{ Corrected temp ${ }^{\circ} \mathrm{C}$} \\
\hline & & & & & & & & & \multirow[b]{2}{*}{1976} & \multirow[b]{2}{*}{1977} & \multirow{2}{*}{$\begin{array}{c}\text { Avg } \\
1976-77 \\
\text { at } 2 \mathrm{~m}\end{array}$} \\
\hline & & & $t^{\circ} \mathrm{C}$ & $\overline{\Delta t}$ & $t^{\circ} \mathrm{C}$ & $\overline{\Delta t}$ & Alt' & Site $^{z}$ & & & \\
\hline 36. & Sand Point $\ldots . . . .$. & 1 & 4.00 & .27 & 3.90 & $\cdots$ & +.9 & +1.5 & 6.4 & 6.3 & 6.1 \\
\hline \multirow[t]{2}{*}{37.} & Pumice Point & $\begin{array}{l}2 \\
1\end{array}$ & $\begin{array}{l}3.73 \\
5.09\end{array}$ & -.59 & $\ddot{5.00}$ & -.60 & +.8 & +1.5 & $\begin{array}{l}6.1 \\
7.4\end{array}$ & 7.3 & \multirow[b]{2}{*}{8.0} \\
\hline & & $\begin{array}{l}2 \\
1\end{array}$ & $\begin{array}{l}5.68 \\
4.76\end{array}$ & & 5.60 & & & & 8.0 & $\begin{array}{l}7.9 \\
7.3\end{array}$ & \\
\hline & Arnica Creek - & $\begin{array}{l}1 \\
2\end{array}$ & $\begin{array}{l}4.76 \\
4.56\end{array}$ & .20 & $\begin{array}{l}4.96 \\
5.02\end{array}$ & -.06 & +.8 & +1.5 & 6.9 & 7.3 & \multirow{2}{*}{7.1} \\
\hline \multirow{2}{*}{39.} & Grant Village & 1 & 6.85 & -1.24 & 7.04 & -1.41 & +.8 & +1.5 & 9.2 & 9.3 & \\
\hline & Falls River & $\begin{array}{l}2 \\
1\end{array}$ & $\begin{array}{l}8.09 \\
6.24\end{array}$ & .39 & $\begin{array}{l}8.45 \\
7.55\end{array}$ & 82 & -1.1 & 0 & 10.4 & 10.8 & 10.6 \\
\hline 41. & & 2 & 5.85 & & 6.73 & .82 & -1.1 & 0 & $\begin{array}{l}5.1 \\
4.8\end{array}$ & $\begin{array}{l}6.5 \\
5.6\end{array}$ & 5.2 \\
\hline 42. & Grassy Lake & 1 & $\begin{array}{l}3.54 \\
3.18\end{array}$ & .36 & 4.14 & .63 & +.3 & +1.0 & 4.8 & 5.4 & \multirow{2}{*}{4.7} \\
\hline & Fossil Forest $\ldots \ldots$ & 1 & $\begin{array}{l}0.10 \\
-\ldots\end{array}$ & $\cdots$ & 4.13 & .70 & +1.4 & 0 & $\begin{array}{l}4.5 \\
\cdots\end{array}$ & $\begin{array}{l}4.8 \\
5.5\end{array}$ & \\
\hline & Flint Creek ..... & $\begin{array}{l}2 \\
1\end{array}$ & $\cdots$ & $\ldots$ & 3.43 & $\cdots$ & +20 & 0 & $\cdots$ & 4.8 & 4.8 \\
\hline & & 2 & $\ldots$ & & 3.95 & & & & $\cdots$ & 6.0 & 6.0 \\
\hline \multicolumn{2}{|c|}{ 47. Timothy Creek } & 1 & $\cdots$ & $\cdots$ & $\cdots$ & $\cdots$ & +1.5 & 0 & $\cdots$ & -- & \multirow{2}{*}{5.2} \\
\hline & Saddle Mountain ............. & 1 & $\cdots$ & $\cdots$ & 2.91 & .45 & +2.8 & 0 & $\cdots$ & $\begin{array}{l}5.2 \\
5.7\end{array}$ & \\
\hline & Little Lamar River $\ldots$ & $\begin{array}{l}2 \\
1\end{array}$ & $\cdots$ & $\ldots$ & $\begin{array}{l}2.46 \\
4.18\end{array}$ & 72 & +.4 & +1.0 & $\cdots$ & $\begin{array}{l}5.3 \\
5.6\end{array}$ & 5.3 \\
\hline & & 2 & $\ldots$ & & 3.46 & & & & $\ldots$ & 4.9 & 4.9 \\
\hline \multicolumn{2}{|c|}{ 50. Cold Creek } & 1 & $\cdots$ & $\cdots$ & 4.76 & .24 & +.3 & 0 & $\cdots$ & 5.1 & 48 \\
\hline & Miller Creek ...... & 1 & $\cdots$ & $-\cdots$ & $\begin{array}{l}1.02 \\
6.28\end{array}$ & .39 & +.2 & 0 & $\cdots$ & 6.5 & 6.0 \\
\hline & Cache Creek (sun) $\ldots \ldots \ldots$ & 1 & $\ldots$ & $\cdots$ & 6.87 & -.07 & -.1 & 0 & $\cdots$ & $\begin{array}{l}6.1 \\
6.8\end{array}$ & 6.1 \\
\hline & Cache Creek (shade). . . . . & $\begin{array}{l}2 \\
1\end{array}$ & $\ldots$ & $\cdots$ & $\begin{array}{l}6.94 \\
-.\end{array}$ & $\ldots$ & -1 & 2.0 & $\cdots$ & $\begin{array}{c}6.8 \\
\ldots\end{array}$ & 6.8 \\
\hline & & 2 & $\ldots$ & & 5.92 & & .1 & & $\cdots$ & 7.8 & 7.8 \\
\hline
\end{tabular}

'All sites are normalized to an altitude of $7000 \mathrm{ft}(2133 \mathrm{~m})$ by applying a lapse rate of $1^{\circ} \mathrm{C}$ per 1000 feet of altitude. 'All sites normalized to a condition where site receives full sun all day.

sSolution of $\mathrm{pH}=3.51$ used for these probes. All other probes contained $\mathrm{pH}=1.93$ Pallmann solution. 
GROUND TEMPERATURES, YELLOWSTONE NATIONAL PARK

TABLE 9.-Instantaneous temperature measurements in degrees Celsius

[Data in italics are estimated. Leaders (. - ) indicate no data. Last column, $\Delta t, 2 \mathrm{~m}$ is the temperature difference between $1978.2 \mathrm{~m}$ and $1979.2 \mathrm{~m}$ ]

\begin{tabular}{|c|c|c|c|c|c|c|c|c|c|c|c|c|c|c|c|c|c|}
\hline \multicolumn{2}{|r|}{ Site } & \multicolumn{3}{|c|}{ Sept.-Oct. 1978} & \multicolumn{3}{|c|}{ Feb. 1979} & \multirow{2}{*}{$\begin{array}{l}3 t . \\
2 \mathrm{~m}\end{array}$} & \multicolumn{2}{|r|}{ Site } & \multicolumn{3}{|c|}{ Sept.Oct. 1978} & \multicolumn{3}{|c|}{ Feb. 1979} & \multirow{2}{*}{$\begin{array}{l}\Delta t \\
2 \mathrm{~m}\end{array}$} \\
\hline No. & Name & $0.5 \mathrm{~m}$ & $1 \mathrm{~m}$ & $2 m$ & $0.5 \mathrm{~m}$ & $\mathrm{~lm}$ & $\overrightarrow{2 m}$ & & No. & Name & $1.5 \mathrm{~m}$ & $1 \mathrm{~m}$ & $2 \mathrm{~m}$ & $\overline{0.5 \mathrm{~m}}$ & $1 \mathrm{~m}$ & $\overline{2 m}$ & \\
\hline 4. & $\begin{array}{l}\text { W. Yellowstone Flow ..... } \\
\text { (shade) }\end{array}$ & 5.4 & 5.1 & 4.7 & 0 & 0.6 & 1.7 & 3.0 & 34 & $\begin{array}{l}\text { Pelican Creek Campground } \\
\text { (shade) }\end{array}$ & 5.5 & 6.8 & 7.7 & $\ldots$ & $\ldots$ & $\cdots$ & 2.0 \\
\hline 7. & Miller Garden ......... & 12.1 & 13.5 & 14.8 & -.1 & 1.3 & T.2 & 7.6 & 35. & Natural Bridge ......... & 6.0 & 7.3 & 8.2 & . . & $\ldots$ & $\ldots$ & 1.5 \\
\hline 8. & Pebble Creek -........... & 6.7 & 7.4 & 6.4 & $\cdots$ & $\cdots$ & $\cdots$ & 3.0 & 36. & Sand Point...$\ldots \ldots \ldots$. & 5.5 & 5.4 & 5.4 & $\ldots$ & $\cdots$ & $\ldots$ & 3.0 \\
\hline 9. & Lamar Ranger Station .... & 7.6 & 7.5 & 6.4 & $\cdots$ & $\ldots$ & $\ldots$ & 3.0 & 37. & Pumice Point ............ & 5.2 & 6.1 & 7.0 & $\ldots$ & $\ldots$ & $\ldots$ & 2.0 \\
\hline 10. & Slough Creek ............ & 10.3 & 9.9 & 8.9 & $\cdots$ & $\ldots$ & $\ldots$ & 3.0 & 38. & Arnica Creek ............ & 6.1 & 6.2 & .. & $\ldots$ & $\ldots$ & $\ldots$ & $\ldots$ \\
\hline 11. & Bunsen Peak ............ & 7.0 & 7.0 & 6.7 & .7 & $1 . \hat{\imath}$ & $3 . \overline{7}$ & 3.0 & 39. & Grant Village ............ & 6.6 & 8.1 & 9.5 & 2.7 & 4.9 & 8.6 & 0.9 \\
\hline 14. & Cougar Creek -.......... & 8.8 & 8.6 & 8.4 & $\cdots$ & $\cdots$ & $\cdots$ & 3.0 & 41. & Falls River $\ldots \ldots \ldots \ldots$ & 9.4 & 9.6 & 8.5 & $\cdots$ & $\ldots$ & $\ldots$ & 3.0 \\
\hline 15. & Mesa Road II . . . . . . . . . & 4.2 & 5.1 & 6.1 & $\ldots$ & $\cdots$ & $\cdots$ & 3.0 & 42 & Grassy Lake ... & 4.5 & 4.9 & 5.0 & $\ldots$ & $\ldots$ & $\ldots$ & 3.0 \\
\hline 16. & Harlequin Lake ... . . . . . & 5.8 & 6.5 & 6.7 & -1.0 & .9 & 4.1 & 2.6 & 45. & Fossil Forest ............. & 6.4 & 6.7 & 6.0 & $\cdots$ & $\ldots$ & $\ldots$ & 3.0 \\
\hline 18. & Cascade Meadows (shade) & 5.2 & 5.1 & 4.9 & -.2 & 1.2 & 2.3 & 2.6 & $4 \bar{i}$ & Timathy Creek .......... & 5.3 & 6.0 & 6.2 & $\ldots$ & $\ldots$ & $\ldots$ & 3.0 \\
\hline 19. & Upper Falls .......... & 5.4 & 5.7 & 6.2 & $\ldots$ & $\cdots$ & $\ldots$ & 3.0 & 48. & Saddle Mountain ....... & 3.4 & 4.3 & 4.3 & $\cdots$ & $\ldots$ & $\ldots$ & 3.0 \\
\hline 20. & Elk Antler Creek .......... & 5.0 & 5.7 & 5.4 & -1.5 & -.3 & 4.1 & 1.3 & 49. & Little Lamar River ....... & 6.2 & 6.7 & 5.1 & $\cdots$ & $\ldots$ & $\cdots$ & 3.0 \\
\hline 21. & Blacktail Deer Dr. . . . . . . & 7.2 & 7.5 & 6.9 & 0 & 2.1 & 4.4 & 2.5 & 50 & Cold Creek .............. & 6.5 & 7.3 & 6.4 & $\cdots$ & $\cdots$ & $\ldots$ & 3.0 \\
\hline 22. & Tower Fall ................. & 7.2 & 7.8 & 7.3 & $\cdots$ & $\ldots$ & $\cdots$ & 3.0 & 51. & Miller Creek.............. & 8.0 & 8.7 & 8.7 & $\ldots$ & $\cdots$ & $\ldots$ & 2.0 \\
\hline 23. & LeHardys Rapids ........ & 4.9 & 4.7 & ... & $\ldots$ & $\cdots$ & $\cdots$ & $\ldots$ & 52 & Cache Creek (sun) ........ & 9.0 & 9.5 & 9.4 & $\ldots$ & .. & $\ldots$ & 1.5 \\
\hline 24. & Grants Pass I . . . . . . . . . & 4.0 & 4.5 & 3.9 & $\ldots$ & $\ldots$ & $\cdots$ & 2.0 & 53. & Cache Creek (shade) ...... & 6.0 & 6.9 & 7.4 & $\ldots$ & $\ldots$ & $\cdots$ & 1.5 \\
\hline 25. & Grants Pass II ......... & 5.3 & 5.3 & 4.3 & $\cdots$ & $\cdots$ & $\cdots$ & 2.0 & 54. & Cascade Meadows (sun) .. & T.5 & 7.6 & 7.5 & .5 & 1.6 & 4.4 & 3.1 \\
\hline 26. & DeLacy Creek .......... & 3.3 & 5.0 & 6.2 & $\ldots$ & .. & $\cdots$ & 2.0 & 55. & Miller Field ............ & 10.4 & 11.5 & 11.9 & -.6 & 1.7 & 5.4 & 6.5 \\
\hline 27. & Divide Lake ......... & 5.8 & 5.5 & 4.8 & -.3 & -.6 & 3.3 & 1.5 & 56. & Gravel Pit ............... & 12.2 & 11.9 & 10.6 & $\ldots$ & $\ldots$ & $\ldots$ & 1.5 \\
\hline 28. & Little Thumb Creek ...... & 4.5 & 4.6 & 4.8 & $\cdots$ & - . & .. & 1.5 & 57. & Lamar Canyon West . . . . . & 9.8 & 9.5 & 9.8 & -1.8 & .6 & 5.5 & 4.3 \\
\hline 29 & Turbid Lake (shade) ..... . & 4.4 & 5.0 & 5.4 & $\cdots$ & $\cdots$ & $\cdots$ & 3.0 & 58. & Lamar Canyon East II .... & 9.9 & 9.4 & 8.4 & $\cdots$ & $\ldots$ & $\cdots$ & 1.5 \\
\hline 30. & Turbid Lake (sun) $-\ldots . .$. & 5.5 & 6.7 & 7.3 & $\ldots$ & $\ldots$ & $\cdots$ & 3.0 & 59. & Ashton ................ & 9.9 & 10.8 & 10.4 & 1.1 & 3.4 & 6.7 & 3.7 \\
\hline 32. & Fishing Bridge - . . . . . & 4.8 & 5.5 & 5.2 & $\cdots$ & $\cdots$ & $\cdots$ & 3.0 & 60 & W. Yellowstone Flow (sun) & 6.9 & 6.8 & 6.7 & .8 & 1.3 & 2.5 & 4.2 \\
\hline 33. & $\begin{array}{l}\text { Pelican Creek Campground } \\
\text { (sun) }\end{array}$ & 7.5 & 8.9 & 9.8 & $\cdots$ & $\cdots$ & $\cdots$ & 1.5 & & & & & & & & & \\
\hline
\end{tabular}




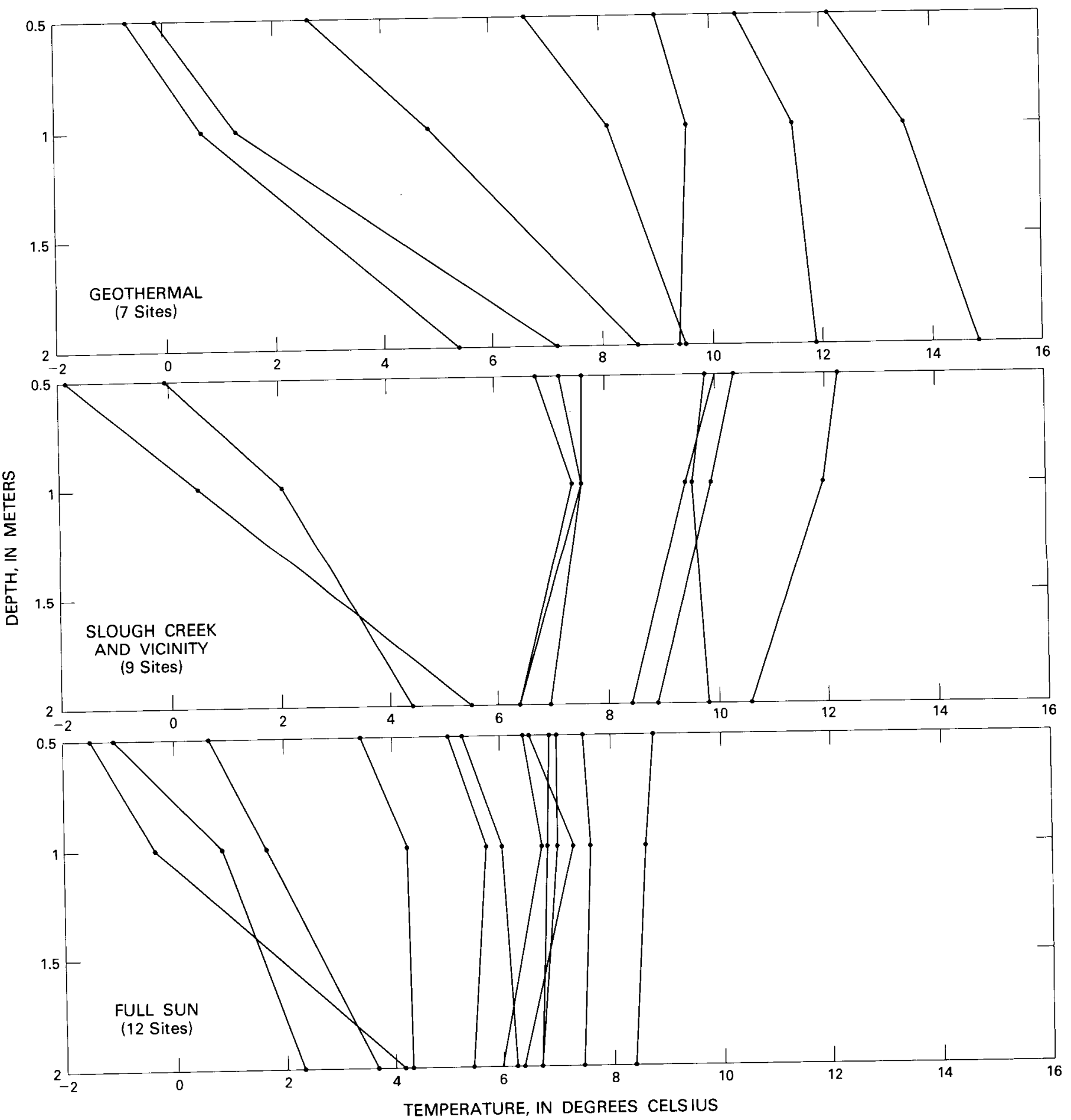

FIGURE 8.-Above and facing page. Plot of instantaneous ground-temperature measurements made in late September 1978, and mid-February 1979. The sites plotted under "geothermal" are those sites that fall in the temperature groupings 3, 4, 5, 6 and 7 in figure 9. Slough Creek plot is from areas of possible anomalous heat flow. 


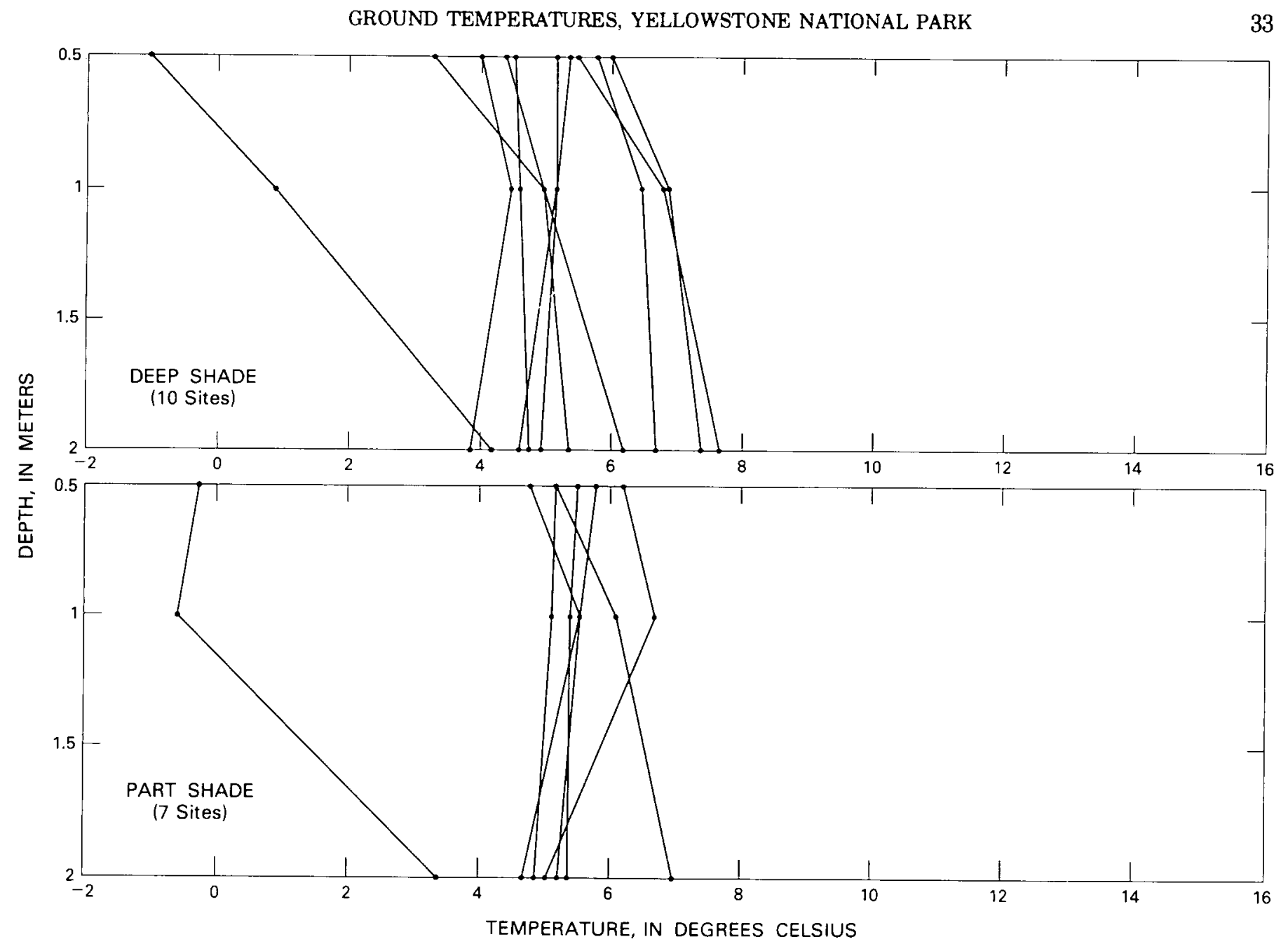


determine the relative heat flow upward from the interior of the Earth, then we must have a method of normalizing all sites to the same net heat flow downward from the ground surface. We attempted to do this for the Yellowstone sites by first making an altitude correction normalizing all sites to an altitude of 7,000 feet. This was first attempted by applying the pseudoadiabatic lapse rate of $2^{\circ} \mathrm{C} / 1000 \mathrm{ft}$ elevation. This altitude correction, when applied to pairs of stations differing only in altitude, did not give corrected temperatures that were equal at the two sites. A correction of $1^{\circ} \mathrm{C}$ per 1,000 feet of elevation yielded corrected temperature values in better accord in each of the paired stations. A lower lapse rate may be due to the sinking of cold air to the valley bottom. This effect, most noticeable in winter, will tend to reduce the normal lapse rate. These corrections are given in table 8 .

The second correction applied to the data was for degree of shade received by the site. A completely open site-one that received all of the available sun all year long-was found to have an effective annual temperature that was $2^{\circ} \mathrm{C}$ higher at a depth of $2 \mathrm{~m}$ than a nearby completely shaded site. After estimating the degree of shade on a scale of 1 through 5 , all sites were normalized to the completely open site condition by adding the appropriate correction (see table 8 ) to the altitudecorrected temperature. These corrections are considered to be a first approximation. Other corrections, such as soil thermal diffusivity, snow cover, and soil albedo, are not easily made, and were not evaluated. The corrected Pallmann temperatures are listed in table 8 . Figure 9 is a map of the area under investigation with the $2-\mathrm{m}$ corrected Pallmann temperatures shown for each site.

To convert Pallmann-effective temperatures to obsidian-effective temperatures and to arithmetic-mean temperatures, the plots (16) in figure 1, PART I were used. The minimum ground temperatures could not be obtained for many sites, and therefore we have estimated the minimum temperature for these sites. These estimated temperatures are shown in italic type in table 9.

The temperature spread between summer maximum and winter minimum at $2 \mathrm{~m}$ is small, $3^{\circ} \mathrm{C}$ or less for most sites. As a result, the difference between Pallmann- and obsidian-hydration effective temperature is $0.1^{\circ} \mathrm{C}$ or less at $2 \mathrm{~m}$ for all sites in the park. This will not be true for obsidian exposed at depths shallower than $2 \mathrm{~m}$. For these samples, the constants used to convert from Pallmannto obsidian-hydration effective temperature can be computed from the $1-\mathrm{m}$ data given in tables 8 and 9 , together with plots in figure 1, PART I.

In terms of snow depth, the winter of 1975-76 was normal. However, the winter of 1976-77 was extremely dry with about one-third the normal snow depth. In 1977-78, about two to three times the normal snow depth was recorded in the park. The 1978-79 winter was extremely cold with no respite through February, 1979. The snowfall was normal, and the ground was insulated from the cold by the snow (1-2 m snow depth by early February).

\section{RESULTS}

As discussed in PART I, the Pallmann temperatures given in table 8 differ from arithmetic-mean annual temperatures. In general, they will show higher readings than "arithmetic" mean annual, because the Pallmann solutions react in a nonlinear manner, that is, the reaction rate is an exponential, rather than a linear, function of temperature. In addition, in areas of normal heat flow, the upper vial will indicate a higher integrated temperature than the lower, again due to the higher temperatures experienced by the upper solutions as compared to the lower. Several sites must have been close to sources of high geothermal heat flow. At these places, extremely high temperatures were recorded at $2 \mathrm{~m}$ and these temperatures were higher than those recorded at $1 \mathrm{~m}$. The Pallmann site near Grant Village was particulariy hot, and we understand that wells drilled in the vicinity of Grant Village have encountered extremely hot water at rather shallow depths. Anomalously high Pallmumn temperatures were also recorded at other sites, including the Slough Creek site and the Norris Junction site.

As mentioned previously, the Slough Creek site (10) yielded anomalously high Pallmann temperatures as compared to similar sites nearby. Additional Pallmann probes were placed at sites adjacent to Slough Creek (sites 43,58 ), and the results are shown in figure 9 . In addition to these Pallmann probes, instantaneous temperature measurements (in September 1978, and February 1979) were made at three places close to the Slough Creek site (sites $56,57,58$ ). These results are given in table 9. All of these results suggest an area of high heat flow in the Slough Creek area.

The winter of 1978-79 was one of the coldest on record. Not only were extremely low temperatures recorded $\left(-56^{\circ}\right.$ Fahrenheit at Old Faithful) but the cold persisted without letup from mid-November 1978, through February 1979. In spite of this, the frost level did not penetrate deeply into the ground. At all but one site, the freezing line was between 0.5 and $1 \mathrm{~m}$. The exception was Elk Antler Creek in Hayden Valley where the freezing line was just below $1 \mathrm{~m}$. This site was exposed to the wind, and the snow depth when we visited in February 1979 , was only about $0.25 \mathrm{~m}$, in contrast to the $1-2 \mathrm{~m}$ of snow cover at all the other sites. Evidently, the lowdensity abundant snow fell early enough in the fall to act as an effective thermal insulation at most sites.

In figure 10 we have plotted the corrected effective annual Pallmann temperatures at $2 \mathrm{~m}$. Inasmuch as the corrections that we have applied to the measured tem- 


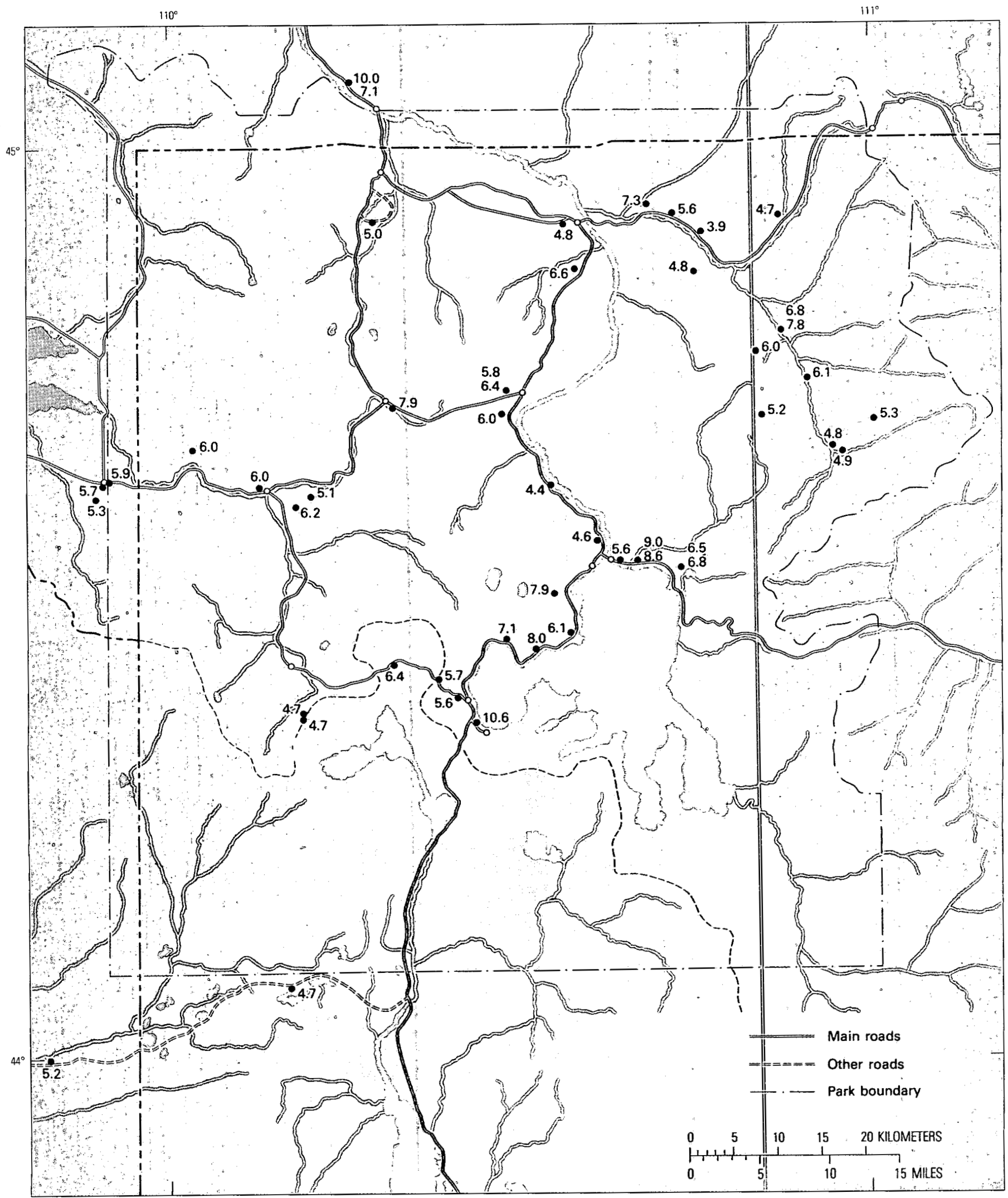

F IGURE 9.-Yellowstone National Park and vicinity with the average corrected 2-m Pallmann temperature for 1976 -1977 shown for each site. These temperatures, in degree Celsius, have been normalized to $7000 \mathrm{ft}(2133 \mathrm{~m})$ and to a site that received all available sun (unshaded). 


\begin{tabular}{|l|llllll}
4 & 5 & 6 & 7 & 8 & 9 & 10 \\
\hline
\end{tabular}

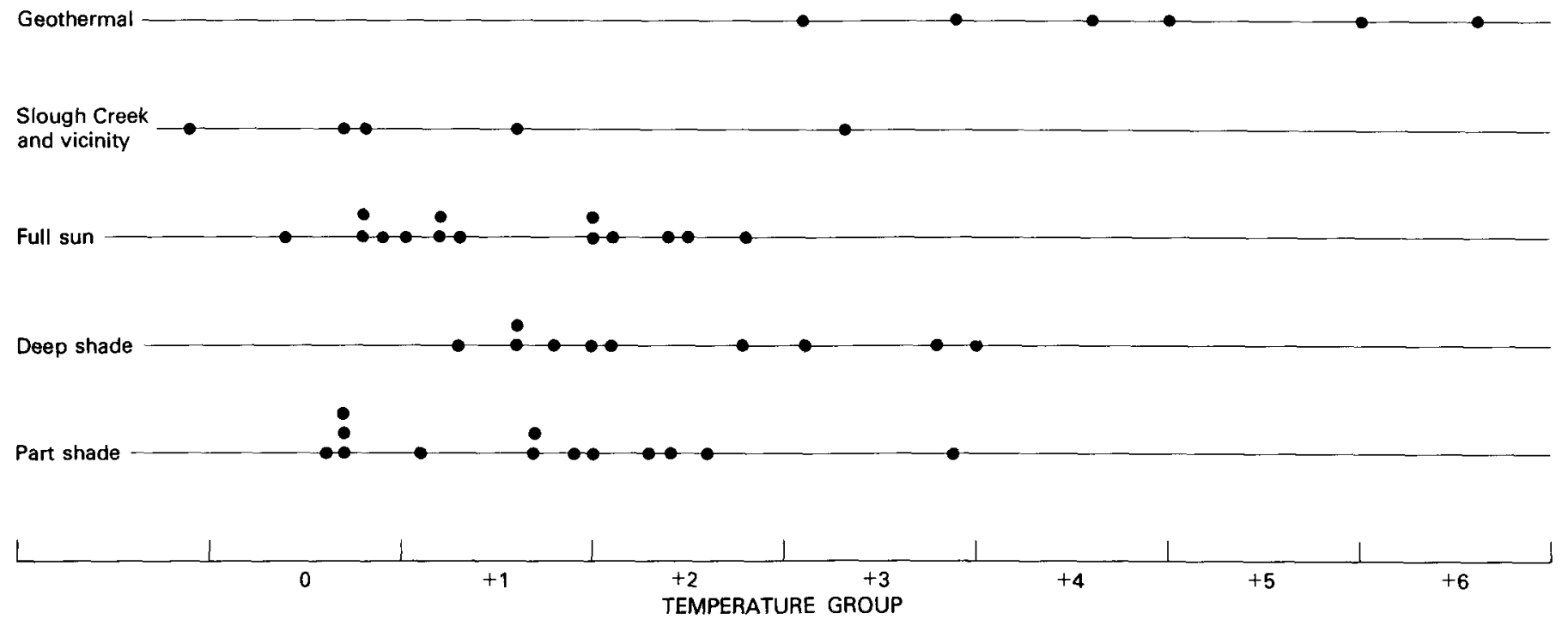

FIGURE 10.-Plot of 2-m corrected Pallmann temperatures, arranged by types of sites: geothermal, Slough Creek and vicinity, full sun, deep shade, and part shade.

peratures have served to normalize these temperatures to a common heat flux from the surface downward, the variations in corrected temperatures at a depth of $2 \mathrm{~m}$ will be due to variable heat flux upward. If the sites with the lowest temperatures, (between $4^{\circ}$ and $5^{\circ} \mathrm{C}$ ) are taken as a base, the corrected temperatures at all other sites can be compared to this group. The sites in the temperature range $5^{\circ}-6^{\circ} \mathrm{C}$ will be designated +1 , those in the range $6^{\circ}-7^{\circ} \mathrm{C},+2$, and so forth. These groupings, from 0 to +6 , are a measure of the amount of geothermal heat flux received by members of each group. The group number is plotted on a map of the Yellowstone area (fig. 11). Areas of high heat flow are also shown enclosed by dotted lines.

Although sites inside the Yellowstone caldera tend to show greater geothermal heat flux than do those outside the caldera, the relatively small number of total sites does not allow us to make a more definitive statement in this regard. The area of high heat flow near Slough Creek is somewhat surprising inasmuch as the closest known hot springs are those on the Yellowstone River, about 4.4 $\mathrm{mi}$ (miles) west of the site. The hot area near Cache Creek is about 2 mi southwest from Wahb Springs (hot) while the Pelican Creek Campground sites are about 2.5 mi from known hot springs. On the other hand, both the LeHardy Rapids and Elk Antler Creek sites are close (LeHardy, $2 \mathrm{mi}$, Elk Antler, $1 \mathrm{mi}$ ) to large thermal areas, and neither site shows any geothermal influence. The two sites at Grants Pass also do not show geothermal effects, even though they are $2 \mathrm{mi}$ from the Shoshone Geyser Basin. Obviously, mere geographic proximity to a geothermal feature is not a sufficient criterion to predict geothermal contribution at a site. The ground-water regime must be the important link in order for a site to display a high geothermal heat flow at 2 -m depth. In fact, the areas containing cool sites are probably places where ground water is moving downwards, whereas the hot sites are caused by warm ascending ground water.

It is interesting to note that site 7 is about $25 \mathrm{yd}$ from a small warm-spring orifice. Site 55 is about $125 \mathrm{yd}$ from site 7 and approximately $150 \mathrm{yd}$ from the spring. The temperature at $2-\mathrm{m}$ depth at site 55 , while still high, is $2.9^{\circ} \mathrm{C}$ less than at site 7 (see table 8 ).

In figure 12 , we have plotted the 2 -m corrected Pallmann temperatures versus the difference in Pallmann temperature recorded by the 1- and 2-m Pallmann vials. In addition to the sites in Yellowstone Park, we have also plotted data from eight sites outside the park; sites that we believe to be remote from the high geothermal heat flow associated with the park. These latter sites define a line (A) shown on the diagram, of positive slope. This means that those sites having the highest temperatures at $2 \mathrm{~m}$ also have the highest positive Pallmann temperature gradient ( $1-\mathrm{m}$ vial higher Pallmann temperature than the $2-\mathrm{m}$ vial). This is in keeping with the higher heat flux downward at these sites. On the other hand, the sites in Yellowstone define a line of negative slope (B). This indicates the greater contribution of upward heat flux at these sites.

The instantaneous temperature measurements made in late September and early October 1978, can be used to aid in delineating the extent of the area of possible 


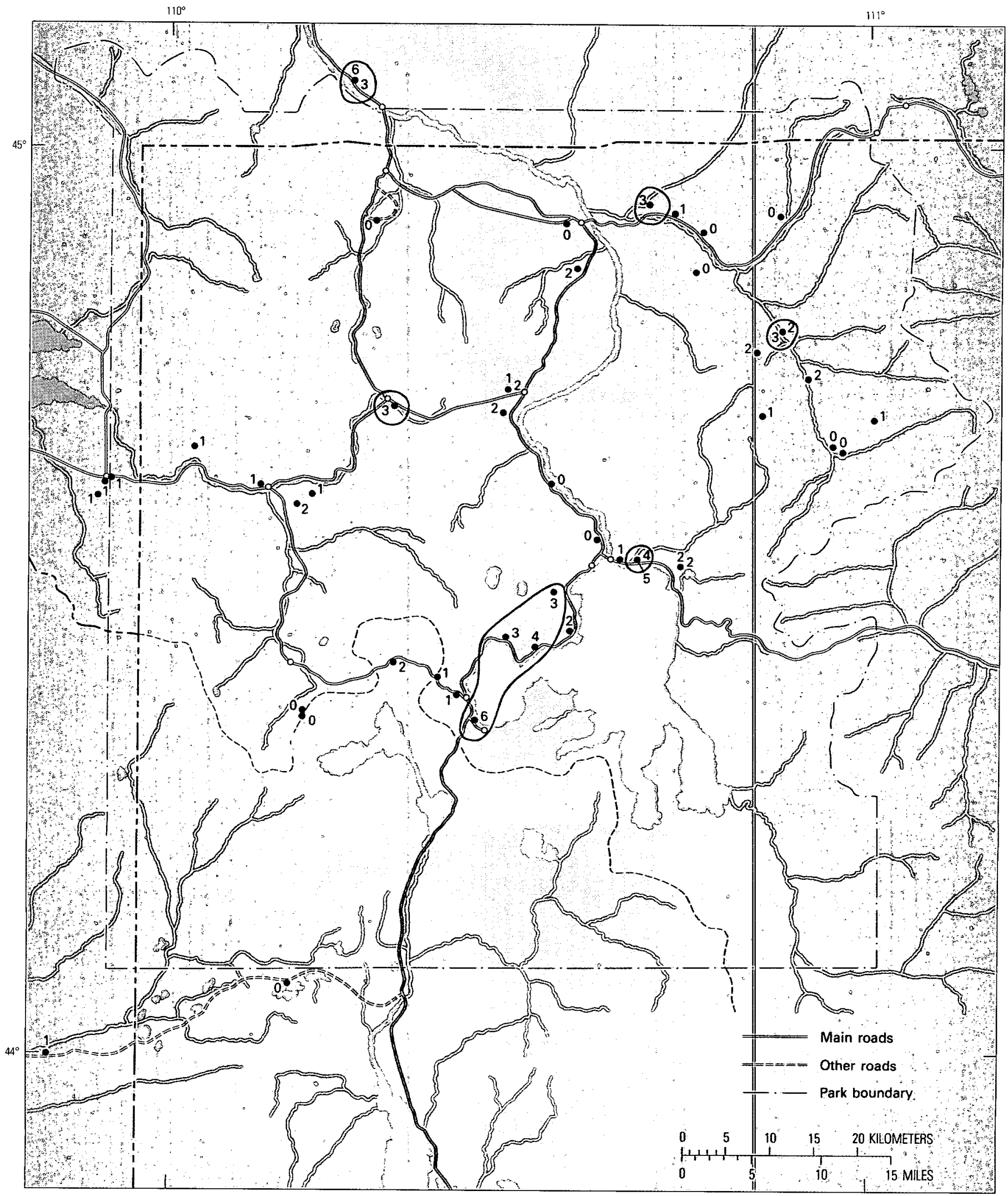

FiguRE 11.-Yellowstone National Park and vicinity showing temperature group (from 0 to +6 degrees Celsius; each group represents a range of $1^{\circ},+1=5^{\circ}-6^{\circ} \mathrm{C} ;+2=6^{\circ}-7^{\circ} \mathrm{C} \ldots$ ) at 48 sites. Areas of high heat flow containing sites with high temperature group values $(+3$ or greater) are shown enclosed by dashed lines. 


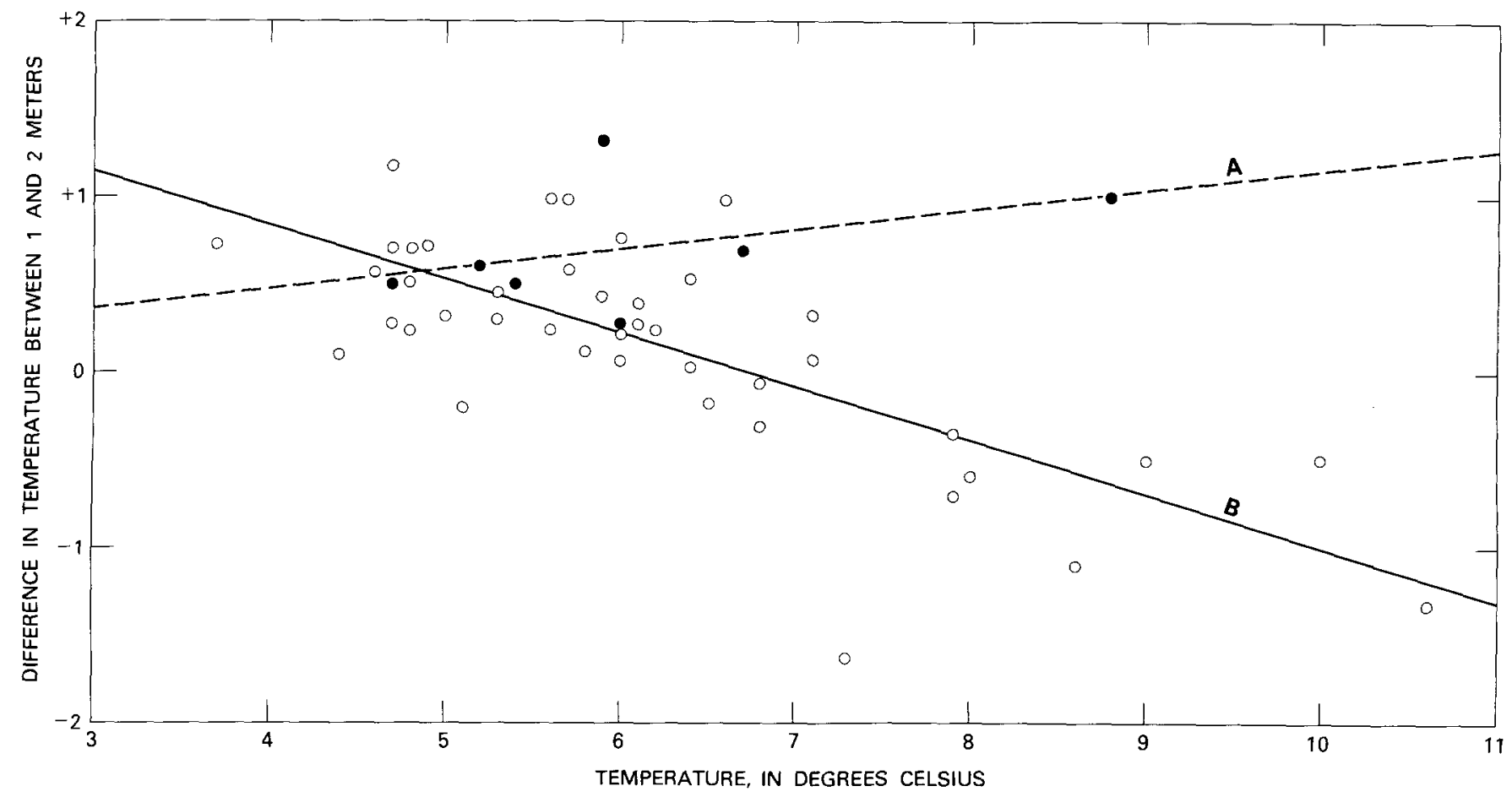

FIGURE 12.-Plot of 2-m corrected Pallmann temperatures versus difference in temperature between 1 and $2 \mathrm{~m}$. Solid circles are from data for sites outside Yellowston National Park that are believed to be remote from geothermal influence. Open circles are data for sites in and adjacent to the park. Lines A and B are least-mean-square fits to the two sets of data points.

anomalous heat flow adjacent to Slough Creek. In figure 13 we have plotted the instantaneous $2-\mathrm{m}$ temperatures, corrected for altitude using the $1^{\circ} \mathrm{C}$ per 1000 feet $(305 \mathrm{~m})$ lapse rate. The data is grouped by whether the sites were in full sun, partial shade, or deep shade. In addition to these groups, the sites that fall in the $+3,+4,+5$, and +6 categories of figure 9 have been plotted as a separate group labeled "geothermal". The group labeled "Slough Creek" are sites adjacent to Slough Creek. Note that sites 8 and 9 which are east of Slough Creek (Pebble Creek and Lamar Ranger Station) as well as site 21, (Blacktail Deer Drive) west of Slough Creek, all fall in the "normal" group having relatively low 2-m instan- taneous temperatures. On the other hand, the sites from just east of Lamar Canyon (site 58) to the gravel pit on the highway west of Slough Creek (site 56) all showed high ground temperatures in the range of the "geothermal" group, the temperature increasing from east to west.

\section{CONCLUSIONS}

In conclusion, the Pallmann measurements made at 1and 2-m depths in and adjacent to Yellowstone National Park can be used to calculate effective obsidianhydration temperatures for dating. The measurements have also been useful in locating and defining areas of 


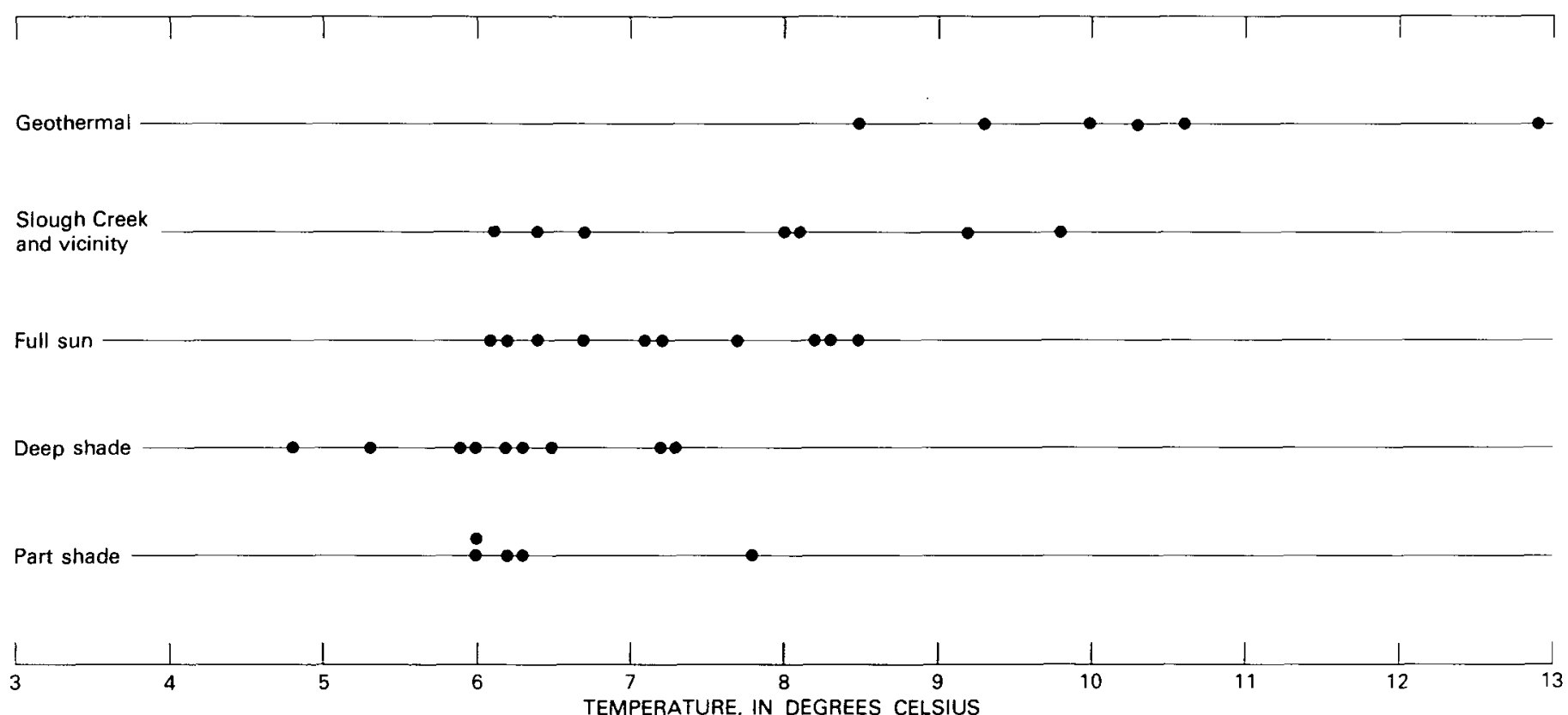

FIGURE 13.-Plot of 2-m instantaneous maximum temperatures made in late September 1978, and normalized to a 7000-ft (2133-m) altitude. Sites are arranged by type: geothermal, Slough Creek and vicinity, full sun, deep shade, and part shade.

anomalous heat flow. Not only did the Pallmann annual effective temperatures measured at $2 \mathrm{~m}$, corrected for altitude and site condition, allow us to locate areas of anomalously high heat flow, but also the temperature gradient between the 1- and 2-m Pallmann vials gave additional indication of such anomalous heat flow.

\section{ACKNOWLEDGMENTS}

This work was made possible by the enthusiastic cooperation of Yellowstone National Park naturalists and rangers. In particular, we wish to thank Alan Mebane and John Tyers. Roger Rudolph arrived in Hayden Valley in the midst of a blizzard to give us much-needed help. Paul Miller and Terry Dansforth were of continual assistance during the four years of this investigation. The remote sites on the Mirror Plateau and Lamar River were serviced by helicopter. Tom Black, who was in charge of the helicopters, was most cooperative in making them available to us.

Dick and Mary Lou Miller kindly allowed us to place probes on their property near Gardiner, Montana, and gave assistance and hospitality.

We wish to thank Fred Cater for his help during the first and most difficult field season. During subsequent seasons we were assisted by Garry Giarratano and Fred Trembour. The difficult and hazardous winter measurements were made with the assistance of Jon Connor.

Design, construction and repair of equipment was carried out by William Long and Joseph Jurceka. Without their help our project could not have functioned. 